\title{
Electrophysiology of ionotropic GABA receptors
}

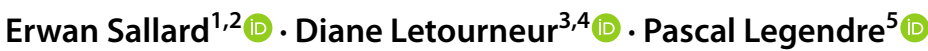

Received: 21 December 2020 / Revised: 2 April 2021 / Accepted: 23 April 2021 / Published online: 1 June 2021

(c) The Author(s) 2021

\begin{abstract}
$\mathrm{GABA}_{\mathrm{A}}$ receptors are ligand-gated chloride channels and ionotropic receptors of GABA, the main inhibitory neurotransmitter in vertebrates. In this review, we discuss the major and diverse roles $\mathrm{GABA}_{\mathrm{A}}$ receptors play in the regulation of neuronal communication and the functioning of the brain. $\mathrm{GABA}_{\mathrm{A}}$ receptors have complex electrophysiological properties that enable them to mediate different types of currents such as phasic and tonic inhibitory currents. Their activity is finely regulated by membrane voltage, phosphorylation and several ions. $\mathrm{GABA}_{\mathrm{A}}$ receptors are pentameric and are assembled from a diverse set of subunits. They are subdivided into numerous subtypes, which differ widely in expression patterns, distribution and electrical activity. Substantial variations in macroscopic neural behavior can emerge from minor differences in structure and molecular activity between subtypes. Therefore, the diversity of $\mathrm{GABA}_{\mathrm{A}}$ receptors widens the neuronal repertoire of responses to external signals and contributes to shaping the electrical activity of neurons and other cell types.
\end{abstract}

Keywords Synaptic receptor $\cdot \mathrm{GABA}_{\mathrm{A}}$ subtypes $\cdot$ Neurotransmitter $\cdot$ Neuronal inhibition $\cdot$ Phasic currents $\cdot$ Tonic activity

\section{Introduction}

$\gamma$-Aminobutyric acid (GABA) is one of the main neurotransmitters in virtually all Metazoans. It is the most widely distributed inhibitory neurotransmitter in the central nervous system of mature vertebrates, being present in around $30 \%$ of the synapses $[1,2]$.

GABA-mediated signals can be transduced in receiving cells through metabotropic or ionotropic receptors located at the plasma membrane. $\mathrm{GABA}_{\mathrm{B}}$ receptors are heterodimeric metabotropic receptors coupled to potassium and calcium

Erwan Sallard

erwan.sallard@ens.psl.eu

1 École Normale Supérieure de Paris, Biology Department, PSL Research University, 45 rue d'Ulm, 75005 Paris, France

2 Department of Human Medicine, Faculty of Health, Center for Biomedical Education and Research (ZBAF), Institute for Virology and Microbiology, Witten/Herdecke University, 58453 Witten, Germany

3 INSERM U1015, Gustave Roussy, Villejuif, France

4 Master de Biologie, École Normale Supérieure de Lyon, Université Claude Bernard Lyon I, Université de Lyon, 69342 Lyon Cedex 07, France

5 Sorbonne Université, UPMC Univ Paris 06, INSERM, CNRS, Neurosciences Paris Seine, Institut de Biologie Paris Seine (NPS, IBPS), 75005 Paris, France channels through $\mathrm{G}$ proteins. On the other hand, $\mathrm{GABA}_{\mathrm{A}}$ receptors are GABAergic pentameric chloride channels [3], i.e. ionotropic GABA receptors, belonging to the cys-loop family of ion channels [4]. Certain ionotropic GABA receptors were initially termed $\mathrm{GABA}_{C}$ receptors [5], but they are now classified as a subset of GABA receptors [6].

$\mathrm{GABA}_{\mathrm{A}}$ receptors are found in all major taxa of bilateral metazoans [7] and are among the most abundant neurotransmitter receptors [8]. They are mainly found in neurons in synaptic, perisynaptic, and extrasynaptic locations. They can also be found in non-neuronal cells as well as outside of the nervous system.

The monomers constituting $\mathrm{GABA}_{\mathrm{A}}$ pentameric receptors are drawn out of a large set of different subunits. Consequently, $\mathrm{GABA}_{\mathrm{A}}$ receptors can be made of different combinations of subunits and are subdivided into subtypes: each subtype corresponds to a combination of subunits. Subtypes can differ in their electrophysiology and their pharmacology. The total number of functional subtypes existing in vivo may reach several hundreds [9], although most receptors belong to one or two dozens of major subtypes [10].

The conductance and current time-course of GABAergic receptor-channels depend on their subunits composition, the ionic conditions of their environment and the patterns of GABA exposure they face. In particular, the differential regulation, abundance and localization of $\mathrm{GABA}_{\mathrm{A}}$ receptor 
subtypes enable a very precise modulation and a great diversity of responses to GABA signals across the brain and the organism, facilitating the numerous biological processes in which $\mathrm{GABA}_{\mathrm{A}}$ receptors are involved.

Despite the complexity and biological significance of $\mathrm{GABA}_{\mathrm{A}}$ receptors, recent reviews on their electrophysiology are missing. In this review, we summarize the current knowledge on the electrophysiology of the different $\mathrm{GABA}_{\mathrm{A}}$ receptor subtypes and show how their properties explain the role they play in cellular and cerebral activity. We mainly focus on mammals and on neuronal $\mathrm{GABA}_{\mathrm{A}}$ receptors. Related subjects such as $\mathrm{GABA}_{\mathrm{A}}$ receptor pharmacology or pathology will not be covered in this review; other reviews have already been published about pharmacology [11-20], the regulation of subunits gene expression [21-23], subunit intracellular trafficking [24, 25], non-neuronal GABA receptors [26-29], and pathology [30-32].

\section{Diversity and structure of $\mathrm{GABA}_{A}$ receptors}

\section{$\mathrm{GABA}_{\mathrm{A}}$ receptor subunits diversity}

Mammals have 19 genes coding for a $\mathrm{GABA}_{\mathrm{A}}$ receptor subunit, classified in classes $(\alpha, \beta, \gamma, \rho, \theta, \varepsilon, \pi$ and $\delta)$ and isoforms ( $\alpha 1-6, \beta 1-3, \gamma 1-3$ and $\rho 1-3)$ [33, 34]. The diversity of subunits is further increased by alternative splicing, to which 9 out of 19 subunits are submitted [34,35]. Alternative splicing enables the $\beta 2, \gamma 2, \gamma 3$ and $\rho 1$ subunit genes to produce at least two mature proteins, but differences in receptor activity depending on alternative splicing have been reported only between the $\gamma 2 \mathrm{~L}$ and $\gamma 2 \mathrm{~S}$ isoforms of the $\gamma 2$ subunit; the main function of alternative splicing is believed to be the regulation of subunit expression [34].

Hundreds of millions of years ago, duplications of an ancestral gene led to the emergence of the different classes of subunits, and later to the different isoforms of a same class. The amino acid identity rate between isoforms of the same class ranges between 70 and $80 \%$, whereas it typically lies between 30 and $40 \%$ for subunits of different classes [36].

Most subunits have remained very stable in the last tens of millions of years of vertebrate evolution. For example, the amino acid identity rate between mouse and human ortholog subunits is above $90 \%$ (except $\rho 3$, with $84 \%$ identity). The conservation is not only structural but also functional: crustacean $\beta$ subunits have been shown to functionally replace human $\beta$ subunits in chimeric receptors [7, 37]. Likewise, deletion of a single $\mathrm{GABA}_{\mathrm{A}}$ receptor subunit often results only in a mild pathology or no phenotype at all [38-42], showing that different subunits can substitute each other. These facts highlight the strong selective pressures applied on $\mathrm{GABA}_{\mathrm{A}}$ receptors, and suggest it has a substantial biological importance.

\section{Subunits assemble into receptors whose structure is finely regulated}

Mature subunits are integral plasma membrane proteins. Human subunits are 420-632 amino acid long and weigh between 52 and $59 \mathrm{kDa}[34,36]$. They contain an extracellular N-terminal segment of 220-250 residues, which can be glycosylated; 4 transmembrane domains termed M1, M2, M3 and M4; and a short extracellular C-terminal segment (Fig. 1a).

A functional receptor contains five subunits (Fig. 1a), assembled in a circle around a chloride-permeable pore delineated by the M2 transmembrane domain of all five subunits [8]. Each monomer is thus in contact with two other subunits, respectively at its "principle", or + , and "complementary", or -, faces.

The study of structure-function relationships of $\mathrm{GABA}_{\mathrm{A}}$ receptors has long been hindered by the substantial diversity of conformations, making it difficult to stabilize a receptor population in a single state [43], and cryo-EM structures of $\mathrm{GABA}_{\mathrm{A}}$ receptors were only recently resolved (reviewed in [44]). GABA-binding sites are located at interfaces between subunits on the surface of the extracellular part of the receptor. GABA binding induces a conformation change, typically when all binding sites are occupied, through a concerted rotation of the extracellular domains of the five monomers [45]. This rotation is translated to the transmembrane domains and results in variations of the opening of the central pore (Fig. 1b). Based on models of $\mathrm{GABA}_{\mathrm{A}}$ receptor structure, Rossokhin predicted that the diameter of the channel pore is mainly controlled by residues- $-2^{\prime}, 9^{\prime}$ and $20^{\prime}$ of the M2 transmembrane domain [46]. The ring formed by the $9^{\prime} \mathrm{M} 2$ residues of the five subunits is termed activation gate. In the main closed conformation, the diameter of the ring is only 2.5-3.4 $\AA$. GABA-induced conformation change prompts the side chains of the activation ring residues to shift away from the central pore, whose diameter increases up to 3.4-7.6 $\AA$, allowing ions to flow through the channel.

The most frequent subunit composition of $\mathrm{GABA}_{\mathrm{A}}$ receptors is $2 \alpha, 2 \beta$ and $1 \gamma$ subunit $[47,48]$. In this case, the 2 $\alpha$ and $2 \beta$ subunits in the receptor are most often, but not always, of the same isoform [48-53] and the receptor carries two GABA binding sites [54] located at the $\beta+/ \alpha-$ subunit interfaces [44]. However, other stoichiometries can be observed [55]: $\varepsilon, \pi$ and $\delta$ subunits can replace a $\gamma$ subunit, and a $\theta$ subunit can replace a $\beta$ subunit [33]. In addition, binary receptors (receptors containing two different classes of subunits instead of three, such as the $\alpha \beta$ subtypes) are able to assemble in vitro. They were also described in vivo, but the evidence of their existence often comes from indirect 
Fig. $1 \mathrm{GABA}_{\mathrm{A}}$ receptor structure and gating. a Structure of an isolated $\mathrm{GABA}_{\mathrm{A}}$ receptor subunit and of a mature receptor. Five subunits, potentially belonging to different classes or isoforms, assemble into a channel permeable to chloride and bicarbonate ions. Ions flow through $\mathrm{GABA}_{\mathrm{A}}$ receptors down their electrochemical gradient. b Control of $\mathrm{GABA}_{\mathrm{A}}$ receptor conductance by the receptor conformation. The central pore can be either closed or open as a result of agonist fixation on the receptor. In this example, the receptor is viewed from the extracellular space and the subunits are ordered as in the most abundant subtypes, namely $\alpha \beta \gamma$. The presence of two GABA binding sites corresponds to ternary receptors (composed of subunits from three different classes) a
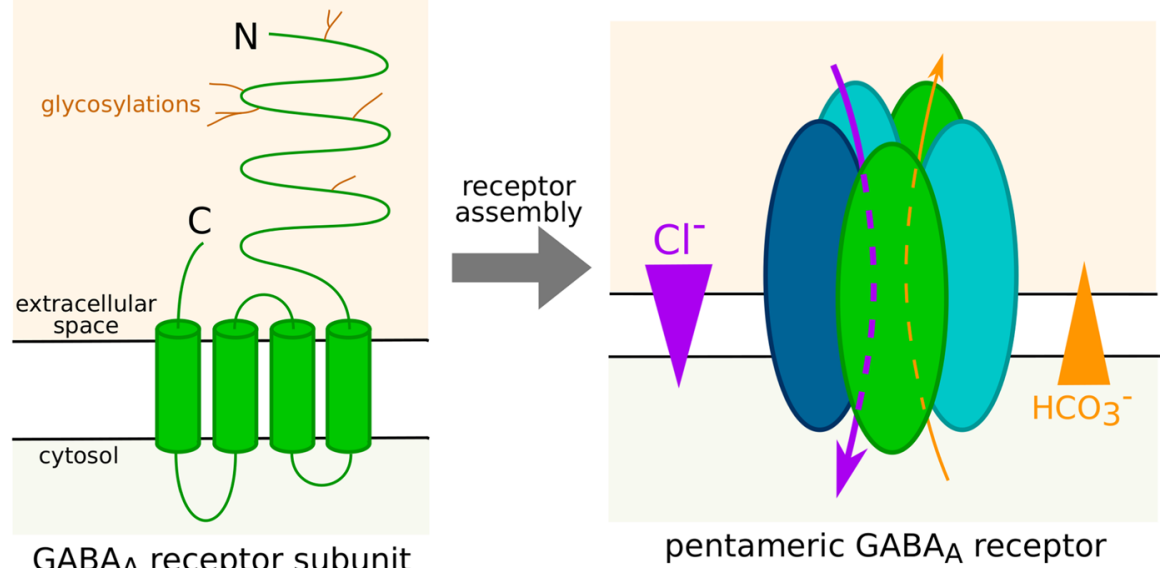

pentameric $\mathrm{GABA}_{\mathrm{A}}$ receptor

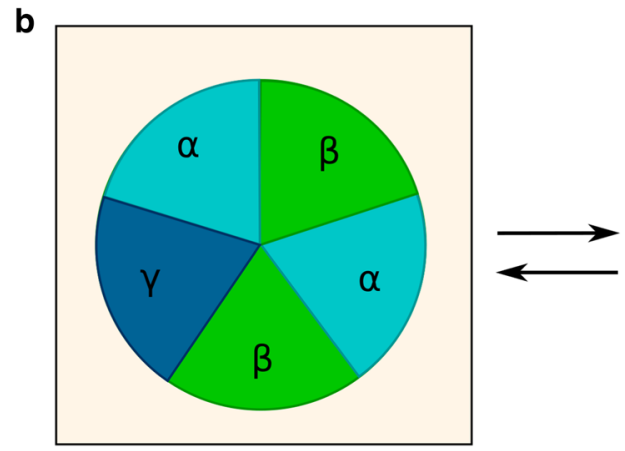

closed central pore

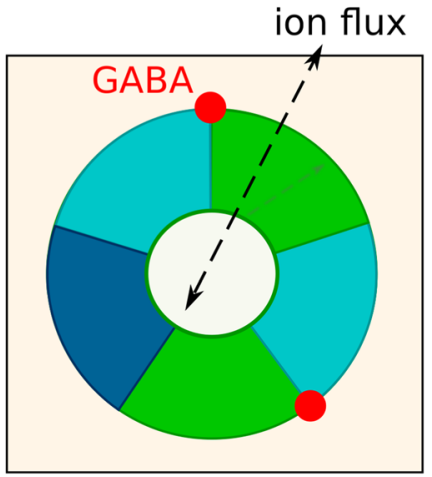

open central pore methods [56] or study of $\gamma 2$ or $\delta$ deficient mice $[57,58]$ : it is therefore possible that they are artefactual or accidental.

$\rho$ subunits usually assemble in homopentamers or heteropentamers $[59,60]$, with five GABA binding sites per receptor [54], i.e. one at each subunit interface. However, in rare cases, $\rho$ subunits assemble with $\alpha 1$ and/or $\gamma 2$ subunits [61, 62].

\section{$\mathrm{GABA}_{A}$ receptors are classified into hundreds of subtypes}

Due to the substantial subunit diversity, there are numerous subtypes of the $\mathrm{GABA}_{\mathrm{A}}$ receptor, characterized by the combination of subunits they contain (e.g. $\alpha 1 \beta 2 \gamma 3$ ) [6].

$\mathrm{GABA}_{\mathrm{A}}$ receptors are expressed in numerous cell types, most notably in neurons. The expression patterns of the different subunits determine which subtypes are assembled, as well as their cellular and subcellular location and their abundance. Numerous cells coexpress multiple $\mathrm{GABA}_{\mathrm{A}}$ subunits isoforms [48-53]. Consequently, a single cell can express several $\mathrm{GABA}_{\mathrm{A}}$ receptor subtypes [56, 63, 64].

The most abundant subtype in the mammalian nervous system is $\alpha 1 \beta 2 \gamma 2$, possibly accounting for $60 \%$ of all $\mathrm{GABA}_{\mathrm{A}}$ receptors [65]. The other major subtypes are $\alpha 2 \beta 3 \gamma 2$ and $\alpha 3 \beta 3 \gamma 2$ [66], while $\alpha 4-6 \beta \gamma 2, \alpha 6 \beta 2-3 \delta, \alpha 4 \beta 2-3 \delta$ and $\rho 1-3$ are less abundant. Minor subtypes whose physiological existence in vivo is deemed likely include $\alpha 1 \beta \delta$, $\alpha 2 \beta 1 \gamma 1, \alpha \beta \varepsilon, \alpha \beta \pi, \alpha \beta \theta, \alpha 1 \alpha 6 \beta \gamma 2, \alpha 1 \alpha 6 \beta \delta$ and $\alpha \beta \gamma 3[10$, 66]. Though it is unlikely that all possible subunit combinations exist and assemble into functional receptors, the large number of possible combinations of subunits expressed by a given cell explains that the number of existing functional subtypes is estimated to be as high as 500 [9]. Most of these subtypes are expected be very rare compared to the most abundant ones [66] and to be limited to a specific tissue, brain area or developmental phase, but they may still exert non-neglectable effects on brain function because of the high abundance of $\mathrm{GABA}_{\mathrm{A}}$ receptors compared to most neuronal receptors [9] and because rare subtypes can be selectively enriched in certain neurons or synapses [12].

\section{$\mathrm{GABA}_{\mathrm{A}}$ receptor ion conductance selectivity}

$\mathrm{GABA}_{\mathrm{A}}$ receptors are ion channels. Different ions can flow down their electrochemical gradient through the pore from one side of the membrane to the other, generating currents. The intensity, i.e. the net charge transfer per time unit, of a 
transmembrane ion current is the product of the ionic electrochemical gradient by the number and conductance of open channels.

$\frac{\mathrm{d} q}{\mathrm{~d} t}=I=N_{\text {open }} \sum_{\text {ions }} \Delta E_{\text {ion }} G_{\text {ion }}$.

$N_{\text {open }}$ is the number of open channels at the considered membrane; it depends on numerous parameters, notably GABA concentration. For each ion, $\Delta E_{\text {ion }}$ designates the cognate transmembrane electrochemical gradient and $G_{\text {ion }}$ the conductance of a single open $\mathrm{GABA}_{\mathrm{A}}$ channel.

The conductance of $\mathrm{GABA}_{\mathrm{A}}$ receptors varies widely for different ions: we will study in this paragraph how this selectivity shapes the currents mediated by $\mathrm{GABA}_{\mathrm{A}}$ receptors.

\section{$\mathrm{GABA}_{A}$ receptor chloride conductance}

In most circumstances in the adult brain, $\mathrm{K}^{+}$coupled secondary active $\mathrm{Cl}^{-}$transporters [67] generate an outwardly directed chloride electrochemical gradient at the neuron plasma membrane [68]. Consequently, GABA-induced opening of $\mathrm{GABA}_{\mathrm{A}}$ receptors induces a chloride influx (Fig. 1a), thus a hyperpolarization of the plasma membrane and an inhibition of action potential generation. This is the most frequent mechanism of inhibitory neurotransmission, which occurs in a large proportion of brain synapses.

However, during development [69], $\mathrm{GABA}_{\mathrm{A}}$ receptors mediate chloride efflux due to an inverted electrochemical gradient [70], and thus often activate the neuron [70-73]. Such a mechanism has also been observed in slices prepared from adult brains [74], but these findings have been questioned because neurons in slices seem to have a higher intracellular chloride concentration than in vivo. This artifact may produce a non-physiological inversion of the chloride electrochemical gradient [75].

Membrane resistivity $(\rho)$ is equal to the transmembrane potential $(\Delta E)$ divided by the intensity $(I)$ of the current passing through a unit of membrane surface: $\rho=\Delta E \times S / I$ (where $S$ is the area of the membrane domain). The lower the resistivity is, the more intense is the transmembrane current generated by a given voltage gradient. The opening of channels, regardless if they mediate depolarizing or hyperpolarizing currents at the resting membrane potential, decreases membrane resistivity and promotes the dissipation of action potentials, a phenomenon termed shunting inhibition. Indeed, it enables ions to respond to the electrochemical gradient created by the action potential with local transmembrane flows instead of the expected longitudinal flows that are necessary for propagating the action potential to other membrane locations. Depolarizing currents mediated by $\mathrm{GABA}_{\mathrm{A}}$ receptors can interfere with action potentials propagation through shunting [76] or inactivation of voltage-dependent $\mathrm{Na}^{+}$channels [77], and can thus be inhibitory instead of excitatory [78, 79]. Conversely, hyperpolarizations mediated by $\mathrm{GABA}_{\mathrm{A}}$ receptors may result in neuronal activation through rebound spikes [80, 81].

The $\mathrm{GABA}_{\mathrm{A}}$ receptor-mediated depolarizations observed during development can induce an influx of calcium through voltage-dependent channels [80, 82], favoring neurite outgrowth [83], synaptogenesis [84], neuron migration [85], and neuron survival [86].

\section{Permeability of GABA $A$ receptors to ions other than chloride}

Although chloride ions account for most of $\mathrm{GABA}_{\mathrm{A}}$ receptor conductance in vivo [3], $\mathrm{GABA}_{\mathrm{A}}$ receptors are also permeable to bicarbonate, formate, propionate, acetate, cyanide and halides $[3,4,87]$. Differences in $\mathrm{GABA}_{\mathrm{A}}$ receptor conductance and permeability to these anions are caused by a selectivity filter relying on recognition sites [3] and the limited pore diameter.

Because of $\mathrm{CO}_{2}$ production and conversion in $\mathrm{HCO}_{3}{ }^{-}$inside the cell, bicarbonate flows mediated by $\mathrm{GABA}_{\mathrm{A}}$ receptors are outwardly directed (Fig. 1a), and thus depolarize the cell membrane. In standard physiological conditions, the ratio of $\mathrm{HCO}_{3}{ }^{-}$vs $\mathrm{Cl}^{-}$permeability of $\mathrm{GABA}_{\mathrm{A}}$ receptors is comprised between 0.2 and 0.3 [88], i.e. chloride currents have a greater amplitude than bicarbonate currents and the net effect is hyperpolarization. However, prolonged GABA exposure can occasionally turn hyperpolarizing currents into depolarizing ones [89], notably during epileptic seizures or in hypothalamic hamartoma neurons [90]. This phenomenon probably indicates a dissipation of the chloride gradient [91, 92] when the channel remains open for long periods. Under these conditions, the bicarbonate efflux may become larger than the chloride influx and $\mathrm{GABA}_{\mathrm{A}}$ receptors may transiently become excitatory [72].

\section{Intrinsic electrophysiological parameters of the different $\mathrm{GABA}_{A}$ receptor subtypes}

The impact of $\mathrm{GABA}_{\mathrm{A}}$ receptors on cellular electrophysiology mostly depends on the time-course and amplitude of the chloride currents evoked by exposure to an agonist such as GABA. Typically, the current time-course following the introduction of an agonist in the receptor's environment consists of an initial current peak, followed by a decrease in amplitude (Fig. 2a). This decrease ends with a stabilization at lower amplitude or a complete closure of the receptors, depending on agonist concentration, duration of exposure to the agonist, and on the receptor subtype. The effects of $\mathrm{GABA}_{\mathrm{A}}$ receptors on neuronal activity are determined primarily by the charge transfer (the product of the current 

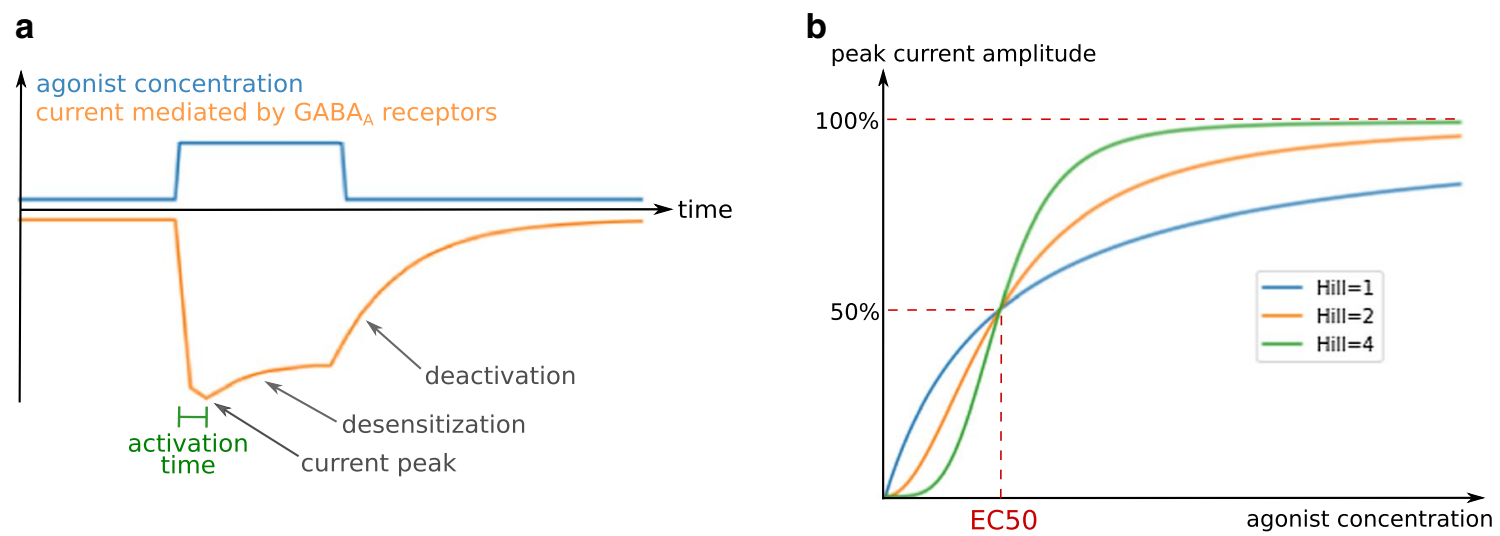

Fig. 2 General characteristics of $\mathrm{GABA}_{\mathrm{A}}$ receptor-mediated currents. a Typical $\mathrm{GABA}_{\mathrm{A}}$ receptor current time-course and kinetic electrophysiological parameters. b Dependence of $\mathrm{GABA}_{\mathrm{A}}$ receptor-mediated current intensity on agonist concentration for different Hill coefficients

intensity with its duration) [93], but also by its synchronization with other electrical inputs, hence the importance of the shape of the current time-course [94, 95]. The current intensity at a certain time point is the product of the conductance of a single channel by the chloride electrochemical gradient and the number of open receptors (Eq. 1), which depends on kinetic parameters governing channel gating as well as receptor and agonist concentrations. Indeed, the effects of an agonist are dose-dependent: for example, the proportion of open receptors as a function of the GABA concentration follows an allosteric pattern (Fig. 2b), characterized by a concentration threshold at which the proportion of open receptors sharply increases.

In most physiological situations, the cell response to a GABA input is driven by the joint action of dozens or hundreds or receptors that perceive the signal. The macroscopic scale (receptor populations) therefore appears more suited than the microscopic scale (single channels) to understand the biological consequences of $\mathrm{GABA}_{\mathrm{A}}$ receptor electrophysiology and is easier to study, which explains that most available information on $\mathrm{GABA}_{\mathrm{A}}$ receptor electrophysiology covers macroscopic features. Nevertheless, macroscopic properties always emerge from the integration of single channel activity characteristics.

The electric activity of $\mathrm{GABA}_{\mathrm{A}}$ receptors can be understood with a series of parameters that describe and explain their responses to the various patterns of agonist exposure. In this section, we will describe the macroscopic electrophysiological parameters that determine the activity of populations of $\mathrm{GABA}_{\mathrm{A}}$ receptors in response to GABA, and we will highlight the differences between subtypes in that regard.

Electrophysiological parameters can be subdivided into kinetic parameters (activation time, desensitization time, deactivation time...) and so-called functional parameters (conductance, EC50, Hill coefficient...), which describe respectively the current time-course and its dependence on agonist concentration. As will be exemplified below, some of these parameters are not independent.

\section{Tools for the study of GABA $\mathrm{A}_{\mathrm{A}}$ receptor electrophysiology}

Before detailing the electrophysiological parameters of $\mathrm{GABA}_{\mathrm{A}}$ receptors, we will discuss two conceptual tools that were instrumental in the discovery and understanding of these parameters: modeling and the use of channel modulating drugs.

\section{Modeling}

Numerous models have been used to interpret the growing amount of data on $\mathrm{GABA}_{\mathrm{A}}$ receptor electrophysiology, predict receptor activity, and understand the microscopic origin of macroscopic parameters and large-scale behavior of channel populations.

Most of the models used are Markovian. Markovian models are discrete (time is discontinuous) and memory-free: the next step of evolution of a model depends only on its present state, and not on past states. Markovian models describe the activity of a channel with a series of states, each of them having its own conductance and being supposed to correspond to a specific receptor conformation. Transition rates can be a function of environmental parameters such as transmembrane potential or agonist concentrations. Transition rates indicate the kinetics of channel activity as well as states occupancy at equilibrium. For example, in the model showed in Fig. 3a, if $p$ is the proportion of receptors in the open state at a given time point, a proportion $p k_{\mathrm{c}}$ of the receptor population transitions to the closed state before the next time point, while a proportion $(1-p) k_{\mathrm{o}}$ of receptor transitions to 
a
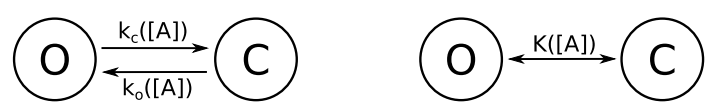

C

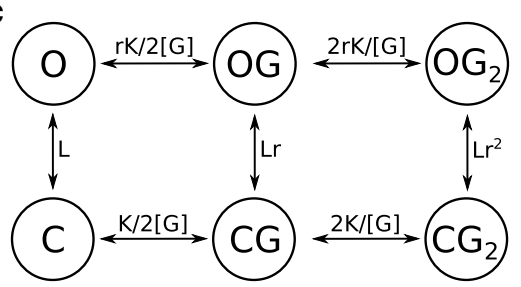

Fig. 3 Markovian models of receptor channel activity. a Simplest Markovian model of a receptor channel, with two unitary states: open $(\mathrm{O})$ and closed $(\mathrm{C})$. The transition rates describing channel opening and closure are respectively $k_{\mathrm{o}}$ and $k_{\mathrm{c}}$. Both transition rates are a function of the agonist concentration $[A]$. b Application of the two-states model to steady-state situations. $K$ is the equilibrium constant, and depends on agonist concentration. $\mathbf{c}$ MWC model. $L, r$ and $K$ are constants depending on receptor structure and $[\mathrm{G}]$ is the GABA concentration. The open states are $\mathrm{O}$ (no GABA bound), OG (one GABA) and $\mathrm{OG}_{2}$ (two GABA); likewise, $\mathrm{C}, \mathrm{CG}$ and $\mathrm{CG} 2$ are the close states

the open state. At equilibrium, the net flux is null, meaning that $p k_{\mathrm{c}}=(1-p) k_{\mathrm{o}}$, and therefore $p=k_{\mathrm{o}} /\left(k_{\mathrm{c}}+k_{\mathrm{o}}\right)$.

Certain models specifically describe systems at equilibrium. This simplification allows the replacement of transition rates by equilibrium constants. In our example model, the equilibrium constant $\mathrm{K}$ would follow the equation $K=p_{\mathrm{eq}} /\left(1-p_{\mathrm{eq}}\right)=k_{\mathrm{o}} / k_{\mathrm{c}}($ Fig. $3 \mathrm{~b})$.

The most classic model used to describe $\mathrm{GABA}_{\mathrm{A}}$ receptor activity is the Monod-Wyman-Changeux two-state concerted transition model (MWC) [96]. This equilibrium model takes into account one open and one closed conformations, both of which can be bound to zero, one or two GABA molecules (Fig. 3c). The MWC model requires only four parameters to entirely describe the receptor response to an agonist, which explains its attractiveness. It accurately describes $\mathrm{GABA}_{\mathrm{A}}$ activity at the macroscopic scale, and its activation by numerous agonists and combination of agonists [47, 96-98]. This model has confirmed the presence of two GABA binding sites on ternary receptors [97].

Other models (Table 1) complexify the MWC model to fit more accurately to certain experimental data, such as the flip model, which includes a transient pre-sensitized closed conformation with high agonist affinity $[96,99]$. More complex models [100-104] consider a greater number of states. Although generally more accurate than simpler models, complex models often lack predictive value since it is difficult to accurately estimate all the parameters of the model [96].

Complex models usually stem from the study of single channels, whose complex behavior requires several states to be accurately described, whereas fewer states are necessary to describe the properties of $\mathrm{GABA}_{\mathrm{A}}$ receptors activity at the synaptic or cellular scale. Despite the likely existence of several conformations, the two-conformations MWC models provide accurate predictions at a macroscopic scale. This indicates that the receptor conformations can be separated into two groups with minor electrophysiological differences within each group [96, 105], or that some of them are occupied only transiently and are not involved in the steady-state circumstances that the MWC model is used to describe.

Electrophysiological parameters can be calculated as a function of transition rates and state occupancies in certain models. Modeling also helps to understand the interdependence between parameters, or to calculate parameters inaccessible to direct experimentation. For example, Chang and Weiss [106] estimated that $\rho$-containing receptors open when they bind GABA in at least 3 of their 5 binding sites.

\section{Channel modulating drugs}

The activity of $\mathrm{GABA}_{\mathrm{A}}$ receptors is modulated by subtypeselective agonists and antagonists belonging to different chemical families such as benzodiazepines or barbiturates and including anesthetic, anxiolytic or antiepileptic drugs.

Since primary and transfected cells can often express several subtypes simultaneously, it is necessary to distinguish from which subtype come the currents measured during electrical recordings. Subtype-selective channel modulating drugs facilitate in situ subtype identification [10].

For example, Lindquist and Birnir performed a patchclamp single-channel study of $\mathrm{GABA}_{\mathrm{A}}$ extrasynaptic receptors on dentate gyrus granule neurones and identified three types of electrophysiological signatures [107]. Receptors of the first, second and third type were potentiated respectively by zolpidem, flumazenil and THDOC, indicating that they belong respectively to $\alpha 1 \beta \gamma 2, \alpha 4 \beta \gamma 2$ and $\alpha \beta \delta$ subtypes.

Table 1 Examples of Markovian steady-state models used for GABA receptor study

\begin{tabular}{lll}
\hline Model & States & Conditions of application \\
\hline MWC & Close, open (both bound to 0, 1 or 2 GABA) & Macroscopic scale \\
Flip model & Resting, resting bound to GABA, pre-sensitized bound, open bound & Macroscopic scale \\
Resting-activated-desensitized & Resting, open, desensitized (all bound to 0, 1 or 2 GABA) & Desensitizing receptors \\
Chang and Weiss model & Close (bound to 0-3 GABA), open & $\rho$-Containing receptors \\
\hline
\end{tabular}


Channel modulating drugs have also been used to study $\mathrm{GABA}_{\mathrm{A}}$ receptors structure and to map subtypes expression in the brain. The benzodiazepine molecules [3H]Ro15-4513 and diazepam bind respectively all $\gamma$-containing subtypes and $\alpha 1,2,3,5 \beta \gamma$ receptors. Hence, under competition from diazepam, [3H]Ro15-4513 binds only $\alpha 4,6 \beta \gamma$ subtypes. Using this property, Korpi et al. mapped $\alpha 4,6 \beta \gamma$ receptors by autoradiography of [3H]Ro15-4513 in mouse brains and showed that they were overexpressed in $\delta-/-$ mice [108]. This proved that $\gamma$ subunits can partly substitute $\delta$.

Etomidate is a general anesthetic binding $\mathrm{GABA}_{\mathrm{A}}$ receptors on their GABA binding sites and potentiating their response to GABA. This potentiation involves comparable allosteric shifts between $\alpha \beta \delta$ and $\alpha \beta \gamma$ subtypes, showing that $\alpha \beta \delta$ subtypes carry two GABA binding sites as had been previously described for $\alpha \beta \gamma$ subtypes [109].

\section{Kinetic parameters}

\section{Activation time}

The delay between a change in GABA concentration and channel response varies between receptor subtypes [110]. The channel opening occurs in two phases: first, agonists bind to the receptor; second, the receptor conformation changes and the central pore opens. Thus, the delay in $\mathrm{GABA}_{\mathrm{A}}$ receptor opening upon GABA introduction in its environment depends both on GABA binding kinetics [111] and on the kinetics of receptor conformational change upon GABA fixation [111]. GABA fixation kinetics is determined by GABA concentration [75, 100, 105], following an allosteric pattern [112], and by the receptor affinity for GABA. At a given GABA concentration, the characteristic time of the GABA binding kinetics is theoretically inversely proportional to the receptor affinity for GABA: this relation has been observed in $\beta 2 \gamma 2 S$-containing subtypes [75]. However, at saturating GABA concentrations (in the order of $10 \mathrm{mM}$ [112]), the conformational change kinetics becomes the limiting factor. This may explain why the $\delta$ subunit lowers the reactivity of the receptor compared to $\gamma 2$ [113] despite a higher affinity. The activation time, i.e. the time to go from 10 to $90 \%$ of open channels after introduction of GABA, is $0.46 \mathrm{~ms}$ for $\alpha 1 \beta 3 \gamma 2 \mathrm{~L}$ at a GABA concentration of $1 \mathrm{mM}$, versus $2.4 \mathrm{~ms}$ for $\alpha 1 \beta 3 \delta$ [114].

The activation times provided in Tables 2, 3 and 4 are calculated at saturating GABA concentration, thus should reflect the kinetics of conformation transition. In association with $\beta 3$ and $\gamma 2 \mathrm{~L}$ subunits, the rank order of $\alpha$ subunits in terms of activation time is $\alpha 1<\alpha 2<\alpha 4<\alpha 6<\alpha 5<\alpha 3$, with $\alpha 3$ being three times slower than $\alpha 1[110-112,114]$. However, when associated with $\beta 1$ and $\gamma 2, \alpha 2$ confers an activation twice faster than $\alpha 1$ [100]. $\alpha \beta$ subtypes [115], and even more $\rho$-containing subtypes [116], display an extremely slow activation time lasting several tens of milliseconds. Receptors containing the $\varepsilon$ subunit display slow activation in vivo [117]. However, this property has never been studied with recombinant $\varepsilon$-containing receptors, thus it may be conferred by another subunit.

The measured activation time depends on the size of the experimental settings. For example, macro-patches, in which several receptors gathered on a micrometric membrane domain are studied, display faster activation than wholecell recordings [112]. It may be due to the time required for GABA to diffuse to all $\mathrm{GABA}_{\mathrm{A}}$ receptors, which is longer for larger experimental models, or to cytoplasmic proteins that may modulate $\mathrm{GABA}_{\mathrm{A}}$ receptor kinetics in whole-cell studies [112].

\section{Desensitization}

Upon long exposure to $\mathrm{GABA}, \mathrm{GABA}_{\mathrm{A}}$ receptors lose their ability to open: this process is called desensitization (Fig. 2a). This mechanism is also observed when receptors are exposed to GABA transients at a high frequency and is then termed rundown (Fig. 4a) [118]. Desensitization prevents the transmission of abnormally strong inhibitory signals during synaptic communication: if GABA is chronically present in the synapse rather than by interspaced bursts, as it is under normal conditions, postsynaptic $\mathrm{GABA}_{\mathrm{A}}$ receptors will close [119].

In desensitized conformations, the M2 transmembrane domains are tilted and their -2 ' residues obstruct the intracellular end of the central pore of $\mathrm{GABA}_{\mathrm{A}}$ channels [46]. The five monomers constituting the channel can transition between open and desensitized conformations independently from one another [120].

During prolonged GABA exposure, the proportion of open channels sometimes follows a decreasing exponential curve over time [75], thereby a characteristic time of desensitization $\left(t_{\mathrm{d}}\right)$ can be calculated. In other cases, the observed desensitization curve can be described as the addition of several exponential components [112, 121, 122] (Fig. 4b). In this situation, a single $t_{\mathrm{d}}$ can be computed as the average of the characteristic times of each component weighted on the amplitude of the related current (this is the procedure followed to calculate the $t_{\mathrm{d}}$ shown in Tables 2, 3 and 4). Consequently, the calculated value of $t_{\mathrm{d}}$ depends on the duration of GABA exposure [111]. In long exposures, slow components gain in relative importance and the calculated $t_{\mathrm{d}}$ increases. In addition, $t_{\mathrm{d}}$ depends strongly on GABA concentration [75]: the curve of desensitization rate as a function of GABA concentration follows approximately an allosteric pattern. When enough data are available for calculations, the $t_{\mathrm{d}}$ presented in Tables 2, 3 and 4 are the asymptote of this curve at infinite GABA concentration. 


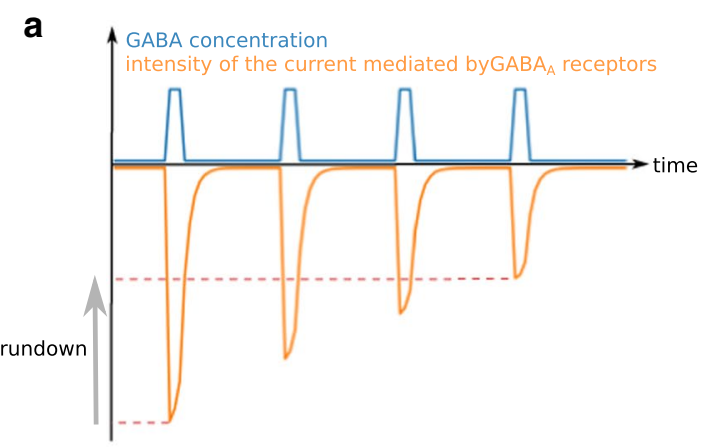

Fig. 4 Characteristics of $\mathrm{GABA}_{\mathrm{A}}$ receptor desensitization. a Rundown. When $\mathrm{GABA}_{\mathrm{A}}$ receptors are exposed to frequent GABA transients, a portion of the receptor population desensitizes at each transient and does not recover before the next exposure, resulting in a

The characteristic time of desensitization is usually in the order of $1 \mathrm{~s}$, despite important variations. $\alpha \beta \gamma$ receptors containing the $\alpha 4$ subunit desensitize two to three times faster than those containing the $\alpha 3$ or $\alpha 5$ subunit, with $\alpha 1$ and $\alpha 2$ desensitizing almost as fast as $\alpha 4$, and $\alpha 6$ conferring an intermediary desensitization time $[75,111,112]$. However, when the receptor includes a $\delta$ subunit, $\alpha 6$ appears to confer faster desensitization than $\alpha 1$ [123]. $\beta 2$ confers a slightly faster desensitization than $\beta 3$, with $\beta 1$ as an intermediate [124] or giving results similar to $\beta 2$ [100]. Desensitization of $\gamma 2$-containing receptors is two or three times faster than that of $\delta$-containing receptors $[113,123,125]$, but substantially slower than that of $\varepsilon$-containing receptors [126].

Certain subtypes do not desensitize or desensitize only partially. For example, homomeric $\rho$-containing receptors are almost insensitive to desensitization [5, 116, 127, 128]. Unlike $\gamma$-containing subtypes, receptors containing the $\delta$ subunit desensitize only partially [101]: $\alpha 1 \beta 3 \delta$ currents decrease by only $11.6 \%$ upon $6 \mathrm{~s}$ exposure to saturating GABA concentration [123]. The $\alpha$ subunit plays a lesser but still notable role in determining the extent of desensitization (Table 5): $\gamma$-containing subtypes desensitize incompletely only if they contain the $\alpha 3$ or $\alpha 5$ subunit [111], with a steady-state current in prolonged GABA exposure of up to $30 \%$ of the peak amplitude. $\alpha 1 \beta 3$ receptors containing two $\alpha$ and three $\beta$ subunits desensitize more extensively than receptors containing three $\alpha$ and two $\beta$ subunits [129].

Desensitization can be followed by a refractory period [114], during which receptors are unable to reopen. The length of this period is modeled as a function of several decreasing exponentials, indicating that $\mathrm{GABA}_{\mathrm{A}}$ receptors can adopt several closed conformations $[114,130]$, whose relative proportions depend on GABA concentration [130]. In vivo, the fast components of the refractory period disappear at low GABA concentration. In these conditions, desensitization is less extensive but its effects last longer [130,

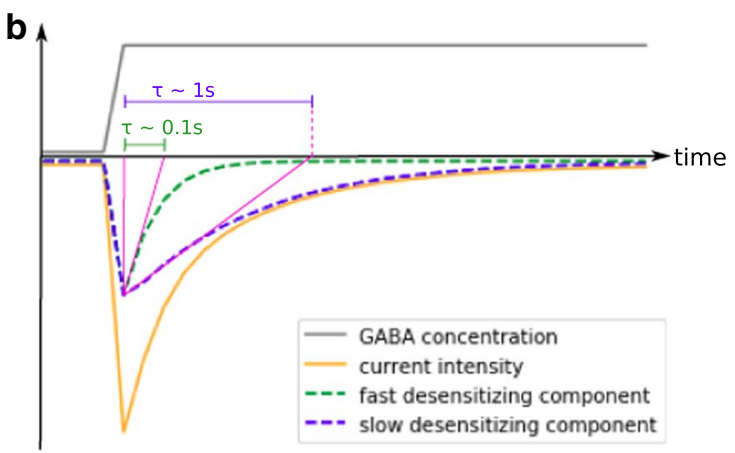

decrease in peak amplitude. b Biphasic desensitization. The current decay upon desensitization can often be modeled as the sum of two decreasing exponential components. A global desensitization rate can be computed from the characteristic time $(\tau)$ of each component.

131]. The length of the refractory period varies between subtypes, with receptors containing $\alpha 4$ or $\alpha 5$ being the fastest to recover (with a characteristic time of $25 \mathrm{~ms}$ following a 5 ms exposure to GABA), followed by $\alpha 2$ and $\alpha 3$ (about 100 $\mathrm{ms}$ ), then $\alpha 1$ (about $200 \mathrm{~ms}$ ) and finally $\alpha 6$ (about $400 \mathrm{~ms}$ ) [111]. Nonetheless, characteristic times heavily depend on experimental procedures and method of calculation [112].

The study of desensitization prompted the development of complex, non-steady-state models of $\mathrm{GABA}_{\mathrm{A}}$ receptor activity since the MWC model does not describe receptor desensitization and therefore applies well only to nondesensitizing subtypes or to short time-frames of activation. These limitations are tackled by three-state models such as the resting-activated-desensitized model (Table 1) [132]. Other models describe the different components of desensitization or refractory periods with several desensitized states $[114,120,133]$; the desensitization times and durations of refractory period components are represented by the transition rates respectively to and from these states. Using one of these models, Gielen et al. [120] proposed that the fast component of desensitization corresponds to receptors with two of their five monomers adopting a desensitized conformation, while the slow component corresponds to receptors with at least three desensitized monomers.

Speed, extent and relative proportions of exponential components of desensitization are critical in shaping the time-course of the inhibitory post-synaptic current (IPSC) mediated by $\mathrm{GABA}_{\mathrm{A}}$ receptors and strongly differ between subtypes [102, 106, 114, 134, 135]. For example, $\alpha 6 \beta 3 \delta$ has no fast component, unlike $\alpha 6 \beta 3 \gamma 2 \mathrm{~L}[101,123]$. Consequently, despite the similarity of the characteristic time of their slow component of desensitization, $\alpha 6 \beta 3 \delta$ appears to desensitize less extensively than $\alpha 6 \beta 3 \gamma 2 \mathrm{~L}$ and is less sensitive to the duration of GABA exposure. As a result, $\alpha 6 \beta 3 \delta$ transmits inhibitory signals whose intensity is roughly proportional to the duration of GABA exposure, 
while $\alpha 6 \beta 3 \gamma 2 \mathrm{~L}$-mediated signals do not depend on exposure duration. This exemplifies that minor differences between subtypes at the microscopic scale can be amplified at larger scales. Furthermore, the time-course of IPSCs determines the strength and timing of neuronal inhibition, so limited differences in desensitization properties can have dramatic effects in the response of neuronal circuits to high-frequency inhibitory signals $[101,136]$.

\section{Deactivation}

$\mathrm{GABA}_{\mathrm{A}}$ receptors spontaneously release their ligands and close several milliseconds or tens of milliseconds after a drop in GABA concentration. The event of deactivation puts an end to the transmission of a hyperpolarizing signal during synaptic communication, after a brief GABA exposure (synaptic GABA bursts usually last no longer than a few milliseconds). Contrary to desensitized channels, deactivated channels can reopen without a refractory period.

Deactivation has been observed to be biphasic in vitro $[100,103,111,114,122,133]$ and in vivo $[105,137]$; the relative proportions of the two components can vary depending on the receptor subtype. These two components may correspond to two conformations, one bound to two GABA molecules (the slow component) and the other to a single one (the fast component) [102], but this hypothesis is debated [114]. Deactivation can sometimes be triphasic [56], once again depending on the subtype and probably on recording procedures, because certain protocols do not enable the recording of very fast components [112].

Homomeric $\rho$-containing receptors deactivate quickly [116]. Among $\alpha$-containing subtypes, those containing $\alpha 4$ are the fastest to close, followed by $\alpha 5$ (1.5 times slower), $\alpha 1$ (2.5 times slower than $\alpha 4$ ), then $\alpha 2$ (5 times slower than $\alpha 4$ ), and finally $\alpha 6$ (6 times slower than $\alpha 4$ ) and $\alpha 3$ (about 10 times slower than $\alpha 4)$. The $\gamma 2$ subunit confers a slower deactivation than $\delta[138,139]$. The $\beta 2$ subunit confers a substantially faster deactivation than $\beta 3$ [140].

Most studies on deactivation have been conducted on whole-cell or multichannel patches, which should give results close to what is observed in vivo at the synaptic or cell scale. However, deactivation is much faster in singlechannel $(0.2-25 \mathrm{~ms})$ than in channel cluster or whole cell (5-680 ms) recordings [141, 142]. This discrepancy likely stems from sequential closing and opening events of a single channel (Fig. 5), which are integrated in a single current time-course by whole-cell or multichannel patches recordings [105, 143]. It exemplifies the apparent gap between the complex macroscopic properties of $\mathrm{GABA}_{\mathrm{A}}$ receptors and the single-channel activity they emerge from.
Fig. 5 Relationships between microscopic and macroscopic kinetics of channel opening. Deactivation is a macroscopic property resulting from the integration of single-channel currents time-courses. Its characteristic time $(\tau)$ is longer than mean channel open time due to possible channel reopening events and is increased by desensitization due to the possible reactivation of desensitized channels without desensitization:

single channel currents:

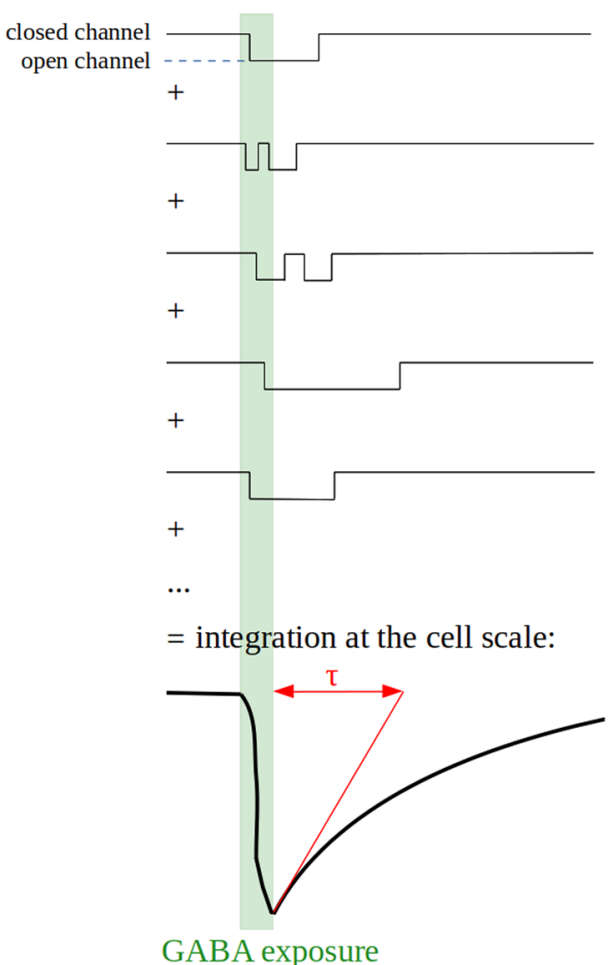

with desensitization:

single channel currents:

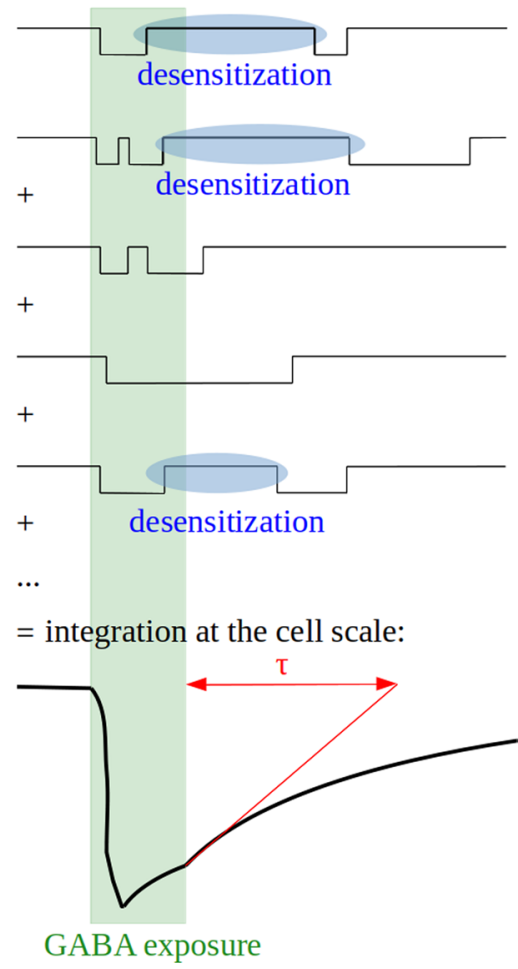


The deactivation time increases in proportion with the extent of desensitization [102, 123, 135], maybe due to a high GABA affinity of desensitized states [135]. GABA is thus retained on desensitized or pre-desensitized receptors for tens of milliseconds, even when all GABA has been cleared from the extracellular space [144]. If the receptor is still bound to GABA when the refractory period ends, it is able to reopen immediately. When numerous receptors are considered together, this process results in a prolongation of the phase in which the current decreases, which is described as a slower deactivation (Fig. 5). Consequently, the fast components of desensitization prolong $\mathrm{GABA}_{\mathrm{A}}$ receptor responses to GABA and therefore synaptic communication while decreasing the current amplitude [102, 131].

\section{Functional parameters}

\section{Conductance}

A single $\mathrm{GABA}_{\mathrm{A}}$ channel can display several conductance states, remarkably conserved between species and cell types, ranging around respectively $12,20,30$ and $45 \mathrm{pS}$ for the most frequent subtypes. The main conductance state is 30 $\mathrm{pS}$, meaning that this is the state adopted by the channel in most circumstances when it is open [4]. The conductance states may correspond to different channel conformations.

Most GABA $_{\mathrm{A}}$ receptor subtypes display very similar conductance values (Tables 2, 3, 4) [145, 146]. However, the main conductance state of $\gamma$-containing receptors $(\sim 30 \mathrm{pS})$ [125] is higher than that of $\delta$-containing receptors ( $22 \mathrm{pS})$ [125], $\rho$-containing receptors (7 or $8 \mathrm{pS})[147,148]$ and $\alpha \beta$ binary subtypes (11-20 pS) [56].

\section{GABA EC50}

The curve of $\mathrm{GABA}_{\mathrm{A}}$ receptor peak current intensity as a function of GABA concentration follows an allosteric pattern (Fig. 2b), described by the equation of Hill:

$\frac{I}{I_{\max }}=\frac{[A]^{h}}{{\mathrm{EC} 50^{h}+[A]^{h}}^{h}}$

where $I$ is the current intensity, $I_{\max }$ its asymptote at infinite agonist concentration, $[A]$ the agonist concentration, and $h$ the Hill coefficient (see "Hill coefficient").

EC50 is the GABA concentration at which the current peak reaches $50 \%$ of its maximal amplitude. The EC50 partially reflects the receptor affinity for GABA: in general, the lower the EC50, the higher the affinity. However, the EC50 also depends on gating parameters such as the speed or maximal probability of channel opening. This can be exemplified by a simple stochastic model with a single binding site and a single opening state.

$$
\begin{gathered}
K_{\text {on }} \\
A+R \underset{\text { off }}{\rightleftharpoons} A R \underset{ }{\rightleftharpoons} A R *,
\end{gathered}
$$

where $A$ is an agonist that binds to a receptor site $R, A+R$ is the vacant state of the receptor site, $A R$ the occupied state, $A R^{*}$ the open state, $K_{\text {on }}$ and $K_{\text {off }}$, respectively the association and dissociation constants of the agonist, and $\beta$ and $\alpha$ are respectively the opening rate and closing rate constants of the channel. In this model, the true affinity of the receptor for its ligand is the microscopic dissociation constant $K_{\mathrm{d}}=K$ off $/ K_{\mathrm{on}}$. The receptor efficacy is defined as the equilibrium constant of the closed-open isomerization $E=\beta / \alpha$. In this model, the apparent affinity EC50 verifies EC50 $=K_{\mathrm{d}} /$ $(1+E)$.

The receptor efficacy is related with Pomax, the maximum fraction of receptors in the active state, by the relation Pomax $=E /(1+E)=1-\left(\mathrm{EC} 50 / K_{\mathrm{d}}\right)$. Pomax can only be estimated at saturating GABA concentration using nonstationary noise analysis [149]. However, the presence of several open states can render the estimation of receptor efficacy very challenging. Hence, the true affinity and efficacy of $\mathrm{GABA}_{\mathrm{A}}$ receptors are often inaccessible to accurate measurements and the EC50 is used as a measure of the apparent affinity.

When certain receptors of a cluster open for the first time upon GABA exposure, others may be already closed, due to fast desensitization. It results in a smoothened shape of the current time-course through decreased peak amplitude and spreading of charge transfer over time. This phenomenon is stronger at high GABA concentrations, which explains why Pomax is often substantially inferior to 1 and EC50 is close to the true affinity $K_{\mathrm{d}}$.

GABA EC50 is up to 100-fold lower than the concentration (termed BC50) at which the probability of occupancy of the GABA binding sites is equal to 0.5 [150], and than the concentration at which the half-maximal activation rate is reached $[100,112]$. This discrepancy is explained by differences in GABA affinity between receptor conformations [106] and by the influence of desensitization on EC50, as confirmed by the small difference between EC50 and BC50 in the non-desensitizing $\rho 1$ subtype [106]. It indicates that the EC50 is not a purely thermodynamic parameter but partially depends on receptor kinetics. Macroscopic parameters of $\mathrm{GABA}_{\mathrm{A}}$ receptor electrophysiology are complex and emerge from the interconnection of the numerous properties of single channels.

Significant differences in GABA EC50 can be observed between $\mathrm{GABA}_{\mathrm{A}}$ receptor subtypes, covering 2 orders of magnitude from around $0.5 \mu \mathrm{M}$ to around $50 \mu \mathrm{M}$. Discrepancies are also observed for the same subtype in different studies, due to differences in the cell type where the receptor was expressed, in the species of origin of the receptor subunits 
or in experimental design (Tables 2, 3, 4). It nonetheless appears that the $\alpha$ subunit plays a crucial role in determining the receptor's affinity for GABA (Table 5 ). The rank order of increasing GABA EC50 is $\alpha 6<\alpha 1 \sim \alpha 2<\alpha 4<\alpha 5<\alpha 3$ when these subunits are associated with $\beta 3$ and $\gamma 2 \mathrm{~S}$ [151], but $\alpha 6<\alpha 4 \sim \alpha 5<\alpha 1<\alpha 2<\alpha 3$ in association with $\beta 3$ and $\gamma 2 \mathrm{~L}$ [111]. The $\beta$ isoform affects GABA affinity to a limited degree, with the $\beta 3$ isoform conferring a one to fourfold lower GABA EC50 than $\beta 1$ and $\beta 2$ (Table 6). The $\gamma 1$ subunit confers a higher EC50 than $\gamma 2$ when these subunits are associated with $\alpha 5$, but in association with $\alpha 3$, the relationship is inverted. Several studies indicate a low EC50 in receptors containing the $\gamma 2 S$ or $\gamma 3$ subunits compared with the $\gamma 2 \mathrm{~L}$ splice variant (Table 7). Receptors containing the $\delta$ subunit consistently display an EC50 around 5 times lower than $\gamma 2$-containing receptors. $\rho$-containing subtypes are around 7 times more sensitive to GABA than the most abundant ternary receptors [147]. Subtypes containing two different isoforms of the same class generally show intermediate properties between the two corresponding subtypes containing only one of these two isoforms [125, 152-157]. Binary receptors have a very low GABA EC50 [146, 158], around $1 \mu \mathrm{M}$, which is as low as the most GABA sensitive ternary receptors. Binary $\alpha 1 \beta 3$ receptors containing two $\alpha$ and three $\beta$ subunits have a lower GABA EC50 than $\alpha 1 \beta 3$ receptors with three $\alpha$ and two $\beta$ subunits [129].

\section{Hill coefficient}

The Hill coefficient of a $\mathrm{GABA}_{\mathrm{A}}$ receptor depends on its number of GABA binding sites and on cooperativity between GABA binding sites, the process by which the binding of GABA to one site increases the affinity or accessibility of the other site(s) for GABA. The higher the number of GABA binding sites or the extent of cooperativity are, the higher the Hill coefficient is. For Hill coefficients higher than 1 , there is a threshold in GABA concentration where the opening probability of the receptor dramatically increases over a limited concentration span. The higher the Hill coefficient, the steeper the threshold (Fig. 2b).

In experimental systems with low temporal resolution, fast desensitization can decrease the resolution of the current peak, which might lead to errors in calculations of Hill coefficients. To the best of our knowledge, this phenomenon has not been tested with $\mathrm{GABA}_{\mathrm{A}}$ receptors, but it was described in the glycine receptor [159] which belongs to the same receptor superfamily as $\mathrm{GABA}_{\mathrm{A}}$ receptors.

Most $\mathrm{GABA}_{\mathrm{A}}$ receptor subtypes have very similar Hill coefficients of around 1.5 . However, binary $\alpha \beta$ receptors and $\varepsilon$-containing receptors display low cooperativity [126, $146,160,161]$ with Hill coefficients below 1. On the opposite, $\rho$-containing subtypes display higher Hill coefficients than the most abundant ternary receptors [106, 128, 162], probably due to the presence of 5 GABA-binding sites instead of 2 [54].

\section{Subunits interplay in the integration of subtype-specific electrophysiologycal properties}

Due to the remarkable evolutionary conservation of the sequence of $\mathrm{GABA}_{\mathrm{A}}$ receptor ortholog subunits, the electrophysiological properties of a certain subtype are expected to be similar in different species. To our knowledge, receptors of the same subtype but different species have never been compared in the same study. Tables 2, 3 and 4 highlight significant differences in the main parameters of certain subtypes between species, but important intraspecies differences are also observed, sometimes even when the subunits are expressed in the same cell line. Indeed, experimental procedures and measurement techniques can have a substantial influence on the results [112]: it can therefore be difficult to compare different subtypes. A further complication is that many authors did not distinguish between the splice variants $\gamma 2 \mathrm{~S}$ and $\gamma 2 \mathrm{~L}$. Still, conclusions can be drawn by comparing subtypes studied in the same article with the same protocols or when several articles give very similar results on the same subtype.

The electrophysiological properties of a ternary subtype are mainly determined by the $\alpha$ subunit isoform and the class of its "third subunit class" (Table 5, 6, 7). Few differences are observed between $\beta$ or $\gamma$ isoforms. Some of the differences observed between $\beta$ isoforms are thought to stem from their differential distribution and association with different isoforms of the $\alpha$ class. For example, preferential association of $\beta 3$ with $\alpha 2$ and $\alpha 3$ instead of $\alpha 1$ is likely to explain the slower kinetics of the $\beta 3$-containing subtypes as compared with the other $\beta$-containing subtypes [193]. Moreover, the electrophysiology of a subtype does not result in a straightforward manner from the addition of the properties conferred by its subunits because of the complex interactions between these subunits: the properties of a subunit depend on its environment within the receptor.

Binary $\alpha \beta$ receptors display low GABA EC50, conductance and Hill coefficient, and activate slowly. In most cases, they desensitize slowly and not extensively, except the $\alpha 1 \beta 3$ subtype which desensitizes as fast and extensively as $\alpha 1 \beta 3 \gamma 2 \mathrm{~L}$ [114]. Despite substantial differences with ternary receptors, binary receptors helped to understand the molecular basis of ternary receptors electrophysiology. For example, using $\alpha \beta 2$ subtypes, Olander et al. [115] showed that differences in activation and desensitization kinetics between $\alpha$ isoforms are determined by their transmembrane and intracellular domains. However, this study didn't identify the cause of variations in deactivation kinetics, since the different $\alpha \beta 2$ subtypes investigated didn't differ significantly in that parameter. Similarly, the extent of desensitization 
Table 2 Main electrophysiological parameters of the different $\mathrm{GABA}_{\mathrm{A}}$ receptor subtypes in standard ionic conditions (subunits expressed in Xenopus oocytes)

\begin{tabular}{|c|c|c|c|c|c|c|}
\hline $\begin{array}{l}\mathrm{GABA}_{\mathrm{A}} \\
\text { receptor } \\
\text { subtype }\end{array}$ & $\begin{array}{l}\text { Single-channel } \\
\text { conductance }(\mathrm{pS})\end{array}$ & GABA EC50 $(\mu \mathrm{M})$ & Hill coefficient & $\begin{array}{l}\text { Characteristic time of } \\
\text { desensitization } t_{\mathrm{d}}(\mathrm{s})\end{array}$ & $\begin{array}{l}\text { Characteristic time } \\
\text { of deactivation (ms) }\end{array}$ & Activation time (ms) \\
\hline$\alpha 1 \beta 1 \gamma 1$ & & $1.2[167]$ & & & & \\
\hline$\alpha 1 \beta 1 \gamma 2$ & 30 [100] & $\begin{array}{l}4.5[167] \\
6[100]\end{array}$ & $1.2[100]$ & $\begin{array}{l}\mathbf{0 . 4 9 2}[100] \\
([\mathbf{G A B A}]=\mathbf{1 ~} \mathbf{m M}) \\
\mathbf{0 . 6}[103] \\
([\mathbf{G A B A}]=\mathbf{1 0 0} \\
\boldsymbol{\mu} \mathbf{M})\end{array}$ & $\begin{array}{l}\mathbf{2 0 . 5}[100] \\
\mathbf{1 7 . 4}[103]\end{array}$ & $\begin{array}{l}1.1[100] \\
\mathbf{1}[103](\gamma \mathbf{2 S} \text { splice variant })\end{array}$ \\
\hline$\alpha 1 \beta 1 \gamma 3$ & & $0.6[167]$ & & & & \\
\hline$\alpha 1 \beta 2 \gamma 1$ & & $\begin{array}{l}0.67 \text { [167] (human } \gamma 1 \text {, rat } \\
\alpha 1 \text { and } \beta 2 \text {, expressed in } \\
293 \text { cells) }\end{array}$ & & & & \\
\hline$\alpha 1 \beta 2 \gamma 2$ & $\begin{array}{l}32[152] \\
27.9[56](\gamma 2 S \\
\quad \text { splice variant })\end{array}$ & $\begin{array}{l}5[172] \\
7[110](\gamma 2 \mathrm{~S} \text { splice variant }) \\
\mathbf{1 . 7 1}[177]\end{array}$ & $\begin{array}{l}1.6[110](\gamma 2 \mathrm{~S} \text { splice } \\
\quad \text { variant }) \\
2.12[152]\end{array}$ & $\begin{array}{l}1.4[110](\gamma 2 S \text { splice } \\
\quad \text { variant })\end{array}$ & $\begin{array}{l}220[110](\gamma 2 S \\
\text { splice variant })\end{array}$ & \\
\hline$\alpha 1 \beta 2 \gamma 3$ & $30.2[178]$ & $1.3[167]$ & & & & \\
\hline$\alpha 1 \beta 2 \delta$ & & $6.71[179]$ & & & & \\
\hline$\alpha 1 \beta 3 \gamma 1$ & & $2.1[167]$ & & & & \\
\hline$\alpha 1 \beta 3 \gamma 2$ & $\begin{array}{l}28[56](\gamma 2 S \text { splice } \\
\text { variant }) \\
27.5[180]\end{array}$ & $\begin{array}{l}1.7[167] \\
2.9[151](\gamma 2 \mathrm{~S} \text { splice } \\
\text { variant) } \\
7.6[181](\gamma 2 \mathrm{~L} \text { splice } \\
\text { variant) } \\
14[112](\gamma 2 \mathrm{~L} \text { splice variant) } \\
\mathbf{3 6 . 2}[158](\gamma 2 \mathrm{~L} \text { splice } \\
\text { variant) } \\
\mathbf{1 4 . 1}[122] \text { ( } \gamma \text { 2L splice } \\
\text { variant) }\end{array}$ & $\begin{array}{l}1.7[158](\gamma 2 \mathrm{~L} \text { splice } \\
\quad \text { variant) }\end{array}$ & $\begin{array}{l}0.424[111] \text { (average } \\
\text { of } 1 \text { and } 3 \mathrm{mM} \text { of } \\
\text { GABA, } \gamma 2 \mathrm{~L} \text { splice } \\
\text { variant) } \\
0.95[112](\gamma 2 \mathrm{~L} \text { splice } \\
\text { variant, } 1 \mathrm{mM} \text { of } \\
\text { GABA) }\end{array}$ & $\begin{array}{l}68.6[111](\gamma 2 \mathrm{~L} \\
\text { splice variant }) \\
143[112](\gamma 2 \mathrm{~L} \\
\text { splice variant }) \\
\mathbf{8 2 . 5}[122](\gamma 2 \mathrm{~L} \\
\text { splice variant })\end{array}$ & $\begin{array}{l}0.55[101](\gamma 2 \mathrm{~L} \text { splice variant }) \\
0.603[111](\gamma 2 \mathrm{~L} \text { splice variant })\end{array}$ \\
\hline$\alpha 1 \beta 3 \delta$ & $27.5[180]$ & $7.4[181]$ & & & $\begin{array}{l}63.4[181] \\
86.8[123]\end{array}$ & \\
\hline$\alpha 2 \beta 1 \gamma 2$ & $\mathbf{3 0}[100]$ & $\begin{array}{l}\mathbf{1 7}[184] \\
\mathbf{3 7}[100]\end{array}$ & $1.8[100]$ & $\begin{array}{l}0.449[100] \\
\quad([\mathrm{GABA}]=\mathbf{~ m M})\end{array}$ & $\begin{array}{l}198.7[100] \\
82 \text { (type 1) or } \mathbf{5 1} \\
\quad(\text { type } 2)[103]\end{array}$ & $\begin{array}{l}0.5[100] \\
0.5[103](\gamma \mathbf{2 S} \text { splice variant })\end{array}$ \\
\hline$\alpha 2 \beta 1 \varepsilon$ & & $11.2[185]$ & & & & \\
\hline$\alpha 2 \beta 2 \gamma 2$ & & $\mathbf{1 . 4 7}[177]$ & & & & \\
\hline$\alpha 2 \beta 3 \gamma 2$ & & $\begin{array}{l}5.2[151](\gamma 2 \mathrm{~S} \text { splice } \\
\quad \text { variant })\end{array}$ & & $\begin{array}{l}0.391[111] \text { (average } \\
\text { of } 1 \text { and } 3 \mathrm{mM} \text { of } \\
\text { GABA, } \gamma 2 \mathrm{~L} \text { splice } \\
\text { variant) }\end{array}$ & $\begin{array}{r}\text { 110.6 }[111](\gamma 2 \mathbf{L} \\
\text { splice variant })\end{array}$ & $\mathbf{0 . 7 3 5}[111]$ ( $\gamma 2 \mathbf{L}$ splice variant $)$ \\
\hline$\alpha 3 \beta 1 \gamma 2$ & & $\begin{array}{l}15.1[167] \text { (human } \alpha 3 \text {, rat } \\
\gamma 2 \text { and } \beta 1 \text {, expressed in } \\
293 \text { cells) }\end{array}$ & & & & \\
\hline$\alpha 3 \beta 2 \gamma 2$ & & $\begin{array}{l}130[187] \\
15.1[167] \text { (human } \alpha 3 \text {, rat } \\
\gamma 2 \text { and } \beta 2, \text { expressed in } \\
293 \text { cells) } \\
75[110](\gamma 2 S \text { splice variant) } \\
\mathbf{2 . 2 1}[177]\end{array}$ & $\begin{array}{l}1.5[110](\gamma 2 \mathrm{~S} \text { splice } \\
\quad \text { variant) } \\
1.1[187]\end{array}$ & $\begin{array}{l}3.2[110](\gamma 2 \mathrm{~S} \text { splice } \\
\quad \text { variant })\end{array}$ & $\begin{array}{l}680[110](\gamma 2 S \\
\text { splice variant })\end{array}$ & \\
\hline$\alpha 3 \beta 3 \gamma 2$ & & $48[151]$ ( $\gamma 2 S$ splice variant $)$ & & $\begin{array}{l}0.701[111] \text { (average } \\
\text { of } 1 \text { and } 3 \mathrm{mM} \text { of } \\
\text { GABA, } \gamma 2 \mathrm{~S} \text { splice } \\
\text { variant) }\end{array}$ & $\begin{array}{c}188.8[111](\gamma 2 \mathrm{~L} \\
\text { splice variant })\end{array}$ & $1.788[111](\gamma 2 \mathrm{~L}$ splice variant $)$ \\
\hline$\alpha 4 \beta 1 \gamma 2$ & & $1.40[177]$ & & & & \\
\hline$\alpha 4 \beta 1 \delta$ & & $\begin{array}{l}\mathbf{0 . 3 0}[188] \\
\mathbf{0 . 1 7}[177]\end{array}$ & $\mathbf{1 . 5 7}[188]$ & & & $174[177]$ \\
\hline$\alpha 4 \beta 2 \gamma 2$ & & $\begin{array}{l}3.9[189] \\
1.4[167]\end{array}$ & & & & \\
\hline$\alpha 4 \beta 2 \delta$ & & $\mathbf{0 . 2 5}[179]$ & & & & \\
\hline$\alpha 4 \beta 3 \gamma 2$ & & $\begin{array}{l}7.6[151](\gamma 2 \mathrm{~S} \text { splice } \\
\quad \text { variant }) \\
15[112](\gamma 2 \mathrm{~L} \text { splice variant })\end{array}$ & & $\begin{array}{l}0.408[111] \text { (average } \\
\text { of } 1 \text { and } 3 \mathrm{mM} \text { of } \\
\text { GABA, } \gamma 2 \mathrm{~L} \text { splice } \\
\text { variant) } \\
0.711[112](\gamma 2 \mathrm{~L} \\
\text { splice variant, } 1 \\
\text { mM of GABA) }\end{array}$ & $\begin{array}{c}24.8[111](\gamma 2 \mathrm{~L} \\
\text { splice variant }) \\
109[112](\gamma 2 \mathrm{~L} \\
\text { splice variant })\end{array}$ & $0.951[111](\gamma 2 \mathrm{~L}$ splice variant $)$ \\
\hline
\end{tabular}


Table 2 (continued)

\begin{tabular}{|c|c|c|c|c|c|c|}
\hline $\begin{array}{l}\mathrm{GABA}_{\mathrm{A}} \\
\text { receptor } \\
\text { subtype }\end{array}$ & $\begin{array}{l}\text { Single-channel } \\
\text { conductance (pS) }\end{array}$ & GABA EC50 $(\mu \mathrm{M})$ & Hill coefficient & $\begin{array}{l}\text { Characteristic time of } \\
\text { desensitization } t_{\mathrm{d}}(\mathrm{s})\end{array}$ & $\begin{array}{l}\text { Characteristic time } \\
\text { of deactivation }(\mathrm{ms})\end{array}$ & Activation time (ms) \\
\hline$\alpha 4 \beta 3 \delta$ & & $\mathbf{0 . 3 5}[188]$ & $1.8[188]$ & & & \\
\hline$\alpha 5 \beta 1 \gamma 2$ & & $5.6[167]$ & & & & \\
\hline$\alpha 5 \beta 2 \gamma^{2}$ & & $\begin{array}{l}5.8[187] \\
4.2[167] \\
\mathbf{0 . 4 7}[177]\end{array}$ & $1.5[187]$ & & & \\
\hline$\alpha 5 \beta 2 \gamma 3$ & & 4.9 [190] & $1.9[190]$ & & & \\
\hline$\alpha 5 \beta 3 \gamma 2$ & $24.9[180]$ & $\begin{array}{l}11.6[151] \text { ( } \gamma 2 \mathrm{~S} \text { splice } \\
\text { variant) }\end{array}$ & & $\begin{array}{l}1.315 \text { [111] (average } \\
\text { of } 1 \text { and } 3 \mathrm{mM} \text { of } \\
\text { GABA, } \gamma 2 \mathrm{~L} \text { splice } \\
\text { variant) }\end{array}$ & $\begin{array}{r}41.5[111](\gamma 2 \mathrm{~L} \\
\text { splice variant })\end{array}$ & $1.247[111]$ ( $\gamma 2 \mathrm{~L}$ splice variant) \\
\hline$\alpha 6 \beta 1 \gamma 2$ & & $0.5[167]$ & & & & \\
\hline$\alpha 6 \beta 2 \gamma 1$ & & 0.4 [167] & & & & \\
\hline$\alpha 6 \beta 2 \gamma 2$ & & $\begin{array}{l}5.2[156](\gamma 2 \mathrm{~S} \text { splice } \\
\quad \text { variant) } \\
1.4[189] \\
0.34[172] \\
\mathbf{0 . 5 0}[179](\gamma 2 \mathrm{~S} \text { splice } \\
\quad \text { variant) }\end{array}$ & & & & \\
\hline$\alpha 6 \beta 2 \delta$ & & $\begin{array}{l}0.52[156](\gamma 2 \mathrm{~S} \text { splice } \\
\quad \text { variant) } \\
1.2[167] \\
\mathbf{0 . 2 1}[179]\end{array}$ & & & & \\
\hline$\alpha 6 \beta 3 \gamma 2$ & & $1[151](\gamma 2 \mathrm{~S}$ splice variant $)$ & & $\begin{array}{l}0.596[111] \text { (average } \\
\text { of } 1 \text { and } 3 \mathrm{mM} \text { of } \\
\text { GABA, } \gamma 2 \mathrm{~L} \text { splice } \\
\text { variant) }\end{array}$ & $\begin{array}{c}163.8[111](\gamma 2 \mathrm{~L} \\
\text { splice variant })\end{array}$ & $1.052[111]$ ( $\gamma 2 \mathrm{~L}$ splice variant) \\
\hline$\alpha 6 \beta 3 \delta$ & & & & & 340.4 [123] & \\
\hline$\rho 1$ & & $1.7[116]$ & $3.5[116]$ & $\begin{array}{l}14.5[116](30 \mu \mathrm{M} \text { of } \\
\text { GABA) }\end{array}$ & & 154 [116] \\
\hline$\rho 2$ & & $2.6[116]$ & $\mathbf{3 . 3}[116]$ & $\begin{array}{l}8.2[116](30 \mu \mathrm{M} \text { of } \\
\text { GABA) }\end{array}$ & & 180 [116] \\
\hline
\end{tabular}

Roman: rat subunits; bold: human subunits; bold italics: mouse subunits. The Hill coefficient, GABA EC50, main conductance state and characteristic times of activation, deactivation and desensitization of the most abundant subtypes in vivo, i.e. ternary subtypes and $\rho$ homopentamers, are presented. Information on other subtypes can be found in $[13,103,112,114,116,123,125,130,146,152-157,176,180$, 182, 191, 192]

of $\alpha \beta \gamma$ receptors was not matched by the corresponding $\alpha \beta$ subtypes, with $\alpha 1 \beta 2$ desensitizing incompletely, contrary to $\alpha 1 \beta 2 \gamma$. This confirms that novel properties emerge from the new subunits interactions introduced by $\gamma$ or $\delta$ subunits in ternary receptors.

Receptors made of $\rho$ subunits react very slowly to changes of GABA concentration, do not desensitize and deactivate quickly; they have low conductance and GABA EC50 but a high Hill coefficient.

The response of $\mathrm{GABA}_{\mathrm{A}}$ receptors to particular GABA inputs can be predicted from the parameters that have been described so far. For example, due to similar conductance, faster activation and slower deactivation, $\alpha 2 \beta 1 \gamma 2$ mediates tenfold higher charge transfers than $\alpha 1 \beta 1 \gamma 2$ when it is activated [100], but the higher GABA EC50 of the former means that stronger inputs are necessary to activate it.

Several studies found a great consistency between the electrophysiological activity of in vitro recombinant and in vivo endogenous $\mathrm{GABA}_{\mathrm{A}}$ receptors $[60,102,103,137$, $152,154,194]$ (reviewed in [195]). The parameter values given above should therefore be relevant enough in physiological contexts to explain the activity and function of $\mathrm{GABA}_{\mathrm{A}}$ receptors in the nervous system.

\section{$\mathrm{GABA}_{\mathrm{A}}$ receptors mediate different types of currents at the neuronal scale}

As receptors of the most abundant inhibitory neurotransmitter, $\mathrm{GABA}_{\mathrm{A}}$ receptors are expressed in most neurons and influence their electric activity. Depending on the neuronal type, $\mathrm{GABA}_{\mathrm{A}}$ receptors can be located in the dendrites, the cell body and/or the axons. They are highly enriched at post-synaptic sites [194, 196], where they usually mediate inhibitory neurotransmission, but can also be found extrasynaptically and perisynaptically. Despite the preferential synaptic localization of $\alpha 1, \alpha 2, \alpha 3$, and especially $\gamma 2$ [197], no $\mathrm{GABA}_{\mathrm{A}}$ receptor subunit has yet been found exclusively in synapses [196, 198]. Receptors containing the $\alpha 4, \alpha 5, \alpha 6, \gamma 1, \gamma 3$ or $\delta$ subunits, as well as binary $\alpha \beta$ subtypes, are mainly extrasynaptic $[56,196$, 
Table 3 Main electrophysiological parameters of the different $\mathrm{GABA}_{\mathrm{A}}$ receptor subtypes in standard ionic conditions (subunits expressed in mouse L929 cells)

\begin{tabular}{|c|c|c|c|c|c|c|}
\hline $\begin{array}{l}\mathrm{GABA}_{\mathrm{A}} \\
\text { receptor } \\
\text { subtype }\end{array}$ & $\begin{array}{l}\text { Single-channel con- } \\
\text { ductance (pS) }\end{array}$ & GABA EC50 $(\mu \mathrm{M})$ & Hill coefficient & $\begin{array}{l}\text { Characteristic time of } \\
\text { desensitization } t_{\mathrm{d}}(\mathrm{s})\end{array}$ & $\begin{array}{l}\text { Characteristic time of } \\
\text { deactivation }(\mathrm{ms})\end{array}$ & Activation time (ms) \\
\hline$\alpha 1 \beta 1 \gamma 1$ & & $5.2[165]$ & & & & \\
\hline$\alpha 1 \beta 1 \gamma 2$ & $\begin{array}{l}30[125](\gamma 2 \mathrm{~L} \text { splice } \\
\text { variant }) \\
29.3[145](\gamma 2 S \text { splice } \\
\text { variant })\end{array}$ & $\begin{array}{l}7.1[146] \\
5.2[168](\gamma 2 L \text { splice } \\
\text { variant) } \\
5.1[169](\gamma 2 L \text { splice } \\
\text { variant) } \\
6.2[125](\gamma 2 \mathrm{~L} \text { splice } \\
\quad \text { variant })\end{array}$ & $\begin{array}{l}1.7[146] \\
1.9[168](\gamma 2 L \text { splice } \\
\text { variant }) \\
1.9[169](\gamma 2 L \text { splice } \\
\text { variant }) \\
1.4[125](\gamma 2 \mathrm{~L} \text { splice } \\
\text { variant })\end{array}$ & & $\begin{array}{l}5[125](\gamma 2 \mathrm{~L} \text { splice } \\
\text { variant) } \\
6.0[145](\gamma 2 S \text { splice } \\
\text { variant })\end{array}$ & \\
\hline$\alpha 1 \beta 1 \delta$ & 22 [125] & & & $\begin{array}{l}\text { No desensitization } \\
\text { observed [125] }\end{array}$ & $400[125]$ & \\
\hline$\alpha 1 \beta 2 \gamma 2$ & $\begin{array}{l}29[145](\gamma 2 S \text { splice } \\
\text { variant) }\end{array}$ & $11[171]$ & & & & \\
\hline$\alpha 1 \beta 3 \gamma 2$ & $\begin{array}{l}25.9[114] \\
26.8[130]\end{array}$ & $\begin{array}{l}14[171] \\
11.6[130](\gamma 2 \mathrm{~L} \\
\text { splice variant) } \\
15.5[111](\gamma 2 \mathrm{~L} \\
\text { splice variant) } \\
15.5[182](\gamma 2 \mathrm{~L} \\
\text { splice variant })\end{array}$ & $\begin{array}{l}1.48[111](\gamma 2 \mathrm{~L} \\
\text { splice variant }) \\
1.5[182](\gamma 2 \mathrm{~L} \text { splice } \\
\text { variant })\end{array}$ & $\begin{array}{l}0.462[114]([\mathrm{GABA}]=1 \\
\mathrm{mM}, \gamma 2 \mathrm{~L} \text { splice variant })\end{array}$ & $\begin{array}{r}76.1[114](\gamma 2 \mathrm{~L} \\
\text { splice variant })\end{array}$ & $\begin{array}{l}0.46[114] \text { ( } \gamma 2 \mathrm{~L} \text { splice } \\
\quad \text { variant })\end{array}$ \\
\hline$\alpha 1 \beta 3 \delta$ & $\begin{array}{l}23.8[114] \\
26.7[130]\end{array}$ & $\begin{array}{l}2.8[130] \\
4.4[182]\end{array}$ & 1.4 [182] & $\begin{array}{l}1.26[114]([\mathrm{GABA}]=1 \\
\mathrm{mM})\end{array}$ & $42.8[114]$ & $2.4[114]$ \\
\hline$\alpha 1 \beta 3 \varepsilon$ & $\begin{array}{l}24[161] \text { (rat } \alpha 1 \text { and } \\
\beta 3 \text {, and human } \varepsilon \text {, in } \\
\text { L929 cells) }\end{array}$ & $\begin{array}{l}0.8[161] \text { (rat } \alpha 1 \text { and } \\
\beta 3 \text {, and human } \varepsilon \\
\text { in L929 cells) }\end{array}$ & $\begin{array}{l}0.9[161] \text { (rat } \alpha 1 \text { and } \\
\beta 3, \text { and human } \varepsilon \\
\text { in L929 cells) }\end{array}$ & & & \\
\hline$\alpha 2 \beta 3 \gamma 2$ & & $\begin{array}{l}25[111](\gamma 2 \mathrm{~L} \text { splice } \\
\text { variant) }\end{array}$ & & & & \\
\hline$\alpha 3 \beta 3 \gamma 2$ & & $\begin{array}{l}35.8[111](\gamma 2 \mathrm{~L} \\
\text { splice variant })\end{array}$ & & & & \\
\hline$\alpha 4 \beta 3 \gamma 2$ & & $\begin{array}{l}10.7[111](\gamma 2 \mathrm{~L} \\
\text { splice variant }) \\
\mathbf{2 . 5 7}[113]\end{array}$ & $\mathbf{1 . 3}$ [113] & $\begin{array}{l}2.5[113]([\mathbf{G A B A}]=100 \\
\quad \mu \mathrm{M})\end{array}$ & & \\
\hline$\alpha 4 \beta 3 \delta$ & & $\mathbf{0 . 5}[113]$ & $\mathbf{1 . 3}[113]$ & $\begin{array}{l}\mathbf{4 . 8}[113]([\mathbf{G A B A}]=\mathbf{1 0 0} \\
\boldsymbol{\mu} \mathbf{M})\end{array}$ & & \\
\hline$\alpha 5 \beta 1 \gamma 2$ & & $\begin{array}{l}32.8[157](\gamma 2 \mathrm{~L} \\
\text { splice variant }) \\
26[124](\gamma 2 \mathrm{~L} \text { splice } \\
\text { variant })\end{array}$ & $\begin{array}{r}1.69[157](\gamma 2 \mathrm{~L} \\
\text { splice variant })\end{array}$ & & & \\
\hline$\alpha 5 \beta 3 \gamma 2$ & $\begin{array}{l}22[133] \text { ( } \gamma 2 \mathrm{~L} \text { splice } \\
\text { variant) }\end{array}$ & $\begin{array}{l}5.7[157](\gamma 2 \mathrm{~L} \text { splice } \\
\text { variant }) \\
6[124](\gamma 2 \mathrm{~L} \text { splice } \\
\text { variant }) \\
9.4[111](\gamma 2 \mathrm{~L} \text { splice } \\
\text { variant })\end{array}$ & $\begin{array}{r}1.54[157](\gamma 2 \mathrm{~L} \\
\text { splice variant })\end{array}$ & & $\begin{array}{r}51.8[133](\gamma 2 \mathrm{~L} \\
\text { splice variant })\end{array}$ & $\begin{array}{l}0.9[133] \text { ( } \gamma 2 \mathrm{~L} \text { splice } \\
\text { variant) }\end{array}$ \\
\hline$\alpha 5 \beta 3 \gamma 3$ & 26.9 [191] & $1.5[191]$ & $1.6[191]$ & & & \\
\hline$\alpha 5 \beta 3 \pi$ & $23.8[191]$ & $1.3[191]$ & 1.4 [191] & & & \\
\hline$\alpha 6 \beta 2 \gamma 2$ & & $2[171]$ & & & & \\
\hline$\alpha 6 \beta 2 \delta$ & & $0.2[171]$ & & & & \\
\hline$\alpha 6 \beta 3 \gamma 2$ & & $\begin{array}{l}2[171](\gamma 2 \mathrm{~L} \text { splice } \\
\text { variant }) \\
2.25[111](\gamma 2 \mathrm{~L} \\
\text { splice variant })\end{array}$ & $\begin{array}{r}1.04[111](\gamma 2 \mathrm{~L} \\
\text { splice variant })\end{array}$ & & & \\
\hline$\alpha 6 \beta 3 \delta$ & & $0.3[171]$ & & & & \\
\hline
\end{tabular}

Roman: rat subunits; bold: human subunits; italics: bovine subunits. The Hill coefficient, GABA EC50, main conductance state and characteristic times of activation, deactivation and desensitization of the most abundant subtypes in vivo, i.e. ternary subtypes and $\rho$ homopentamers, are presented. Information on other subtypes can be found in [13, 103, 112, 114, 116, 123, 125, 130, 146, 152-157, 176, 180, 182, 191, 192] 
Table 4 Main electrophysiological parameters of the different $\mathrm{GABA}_{\mathrm{A}}$ receptor subtypes in standard ionic conditions (subunits expressed in Xenopus oocytes)

\begin{tabular}{|c|c|c|}
\hline $\mathrm{GABA}_{\mathrm{A}}$ receptor subtype & GABA EC50 $(\mu \mathrm{M})$ & Hill coefficient \\
\hline$\alpha 1 \beta 1 \gamma 1$ & $\begin{array}{l}25[163] \\
41[164] \\
75[166]\end{array}$ & \\
\hline$\alpha 1 \beta 1 \gamma 2$ & $\begin{array}{l}9.8[170] \text { ( } \gamma 2 S \text { splice variant }) \\
19.9[126](\gamma 2 S \text { splice variant })\end{array}$ & $1.36[126](\gamma 2 S$ splice variant $)$ \\
\hline$\alpha 1 \beta 1 \delta$ & $4.9[170]$ & \\
\hline$\alpha 1 \beta 1 \varepsilon$ & $\mathbf{4 . 0}[126]$ & $\mathbf{0 . 8 5}[126]$ \\
\hline$\alpha 1 \beta 2 \gamma 2$ & $\begin{array}{l}41[153] \\
16[132](\gamma 2 \mathrm{~L} \text { splice variant) } \\
45.8[47,173,174] \\
34[97](\gamma 2 \mathrm{~L} \text { splice variant }) \\
55[175] \\
\mathbf{2 0}[155] \\
\mathbf{2 0}[163] \\
\mathbf{4 . 6 1}[176] \text { ( } 2 \text { L } \text { splice variant })\end{array}$ & $\begin{array}{l}1.39[153] \\
1.59[174] \\
1.57[47,173] \\
1.38[97](\gamma 2 \mathrm{~L} \text { splice variant }) \\
1.4[175] \\
\mathbf{1 . 3 8}[176](\gamma 2 L \text { splice variant })\end{array}$ \\
\hline$\alpha 1 \beta 3 \gamma 2$ & $8[163]$ & \\
\hline$\alpha 2 \beta 1 \gamma 1$ & 39.8 [183] & \\
\hline$\alpha 2 \beta 1 \gamma 2$ & $30.6[183]$ & \\
\hline$\alpha 3 \beta 1 \gamma 1$ & $\mathbf{1 1 4}[163]$ & \\
\hline$\alpha 3 \beta 1 \gamma 2$ & $\begin{array}{l}240[154] \\
\mathbf{2 0 8}[163] \\
\mathbf{2 0 0}[186](\gamma \mathbf{2 S} \text { splice variant) } \\
98[164]\end{array}$ & \\
\hline$\alpha 3 \beta 1 \gamma 3$ & $32[163]$ & \\
\hline$\alpha 3 \beta 1 \varepsilon$ & $2.3[186]$ & \\
\hline$\alpha 3 \beta 1 \theta$ & $81[186]$ & \\
\hline$\alpha 3 \beta 2 \gamma 2$ & $\begin{array}{l}487[154] \\
\mathbf{1 1}[163]\end{array}$ & \\
\hline$\alpha 3 \beta 3 \gamma 2$ & 28 [163] & \\
\hline$\alpha 5 \beta 1 \gamma 2$ & $\begin{array}{l}17[154] \\
\mathbf{1 5}[163]\end{array}$ & \\
\hline$\alpha 5 \beta 2 \gamma 2$ & $14[154]$ & \\
\hline$\alpha 5 \beta 3 \gamma 1$ & $24[163]$ & \\
\hline$\alpha 5 \beta 3 \gamma 2$ & $3[163]$ ( $\gamma 2 \mathrm{~L}$ splice variant $)$ & \\
\hline$\alpha 5 \beta 3 \gamma 3$ & 2 [163] & \\
\hline$\alpha 6 \beta 2 \gamma 2$ & $\begin{array}{l}6.7[153] \\
\mathbf{1 . 6}[155]\end{array}$ & $0.82[153]$ \\
\hline$\rho 1$ & $\mathbf{0 . 8 1}[106]$ & $\mathbf{2 . 8 3}[106]$ \\
\hline$\rho 2$ & $1.19[162]$ & $2.17[162]$ \\
\hline
\end{tabular}

Roman: rat subunits; bold: human subunits; italics: bovine subunits; bold italics: mouse subunits. The Hill coefficient, GABA EC50, main conductance state and characteristic times of activation, deactivation and desensitization of the most abundant subtypes in vivo, i.e. ternary subtypes and $\rho$ homopentamers, are presented. Information on other subtypes can be found in $[13,103,112,114,116,123,125,130,146,152-157,176$, $180,182,191,192]$

197, 199], although the $\alpha 4, \alpha 5$ and $\alpha 6$ subunits can also be found in synapses at medium concentrations.

Due in part to the diversity in electrophysiology of the different subtypes, $\mathrm{GABA}_{\mathrm{A}}$ receptors mediate several types of currents in neurons. These currents, and by extension the subtypes involved in their generation, have different biological functions.

\section{Phasic activity}

Post-synaptic $\mathrm{GABA}_{\mathrm{A}}$ receptors primarily have a phasic activity: they mediate intense currents of regulated duration upon binding GABA molecules released in the synaptic cleft by the pre-synaptic neuron. Phasic receptors are involved in synaptic communication and are the main mediators of inhibitory signals [200]. The most abundant synaptic receptors of the mature brain belong to subtypes containing the $\gamma 2$ subunit associated with $\beta$ subunits and $\alpha 1$ or $\alpha 2$ [114, 201]. Their electrophysiological properties (see Tables 5, 6, 7 ) ensure the speed and specificity of inhibitory post-synaptic currents (IPSCs) generated in response to pre-synaptic GABA release, ensuring efficient neuronal communication. Indeed, the GABA concentration reaches $2-5 \mathrm{mM}$ in the 
Table 5 Properties conferred by the "first subunit class" of the receptor

\begin{tabular}{lllllll}
\hline isoform & $\alpha 1$ & $\alpha 2$ & $\alpha 3$ & $\alpha 4$ & $\alpha 5$ & $\alpha 6$ \\
\hline $\begin{array}{llll}\text { GABA EC50 } \\
\text { Desensitization }\end{array}$ & $\begin{array}{l}\text { Medium } \\
\text { Complete and } \\
\text { moderately fast }\end{array}$ & $\begin{array}{l}\text { Medium } \\
\text { Complete and } \\
\text { moderately fast }\end{array}$ & $\begin{array}{l}\text { Very high } \\
\text { Slow and incomplete }\end{array}$ & $\begin{array}{l}\text { Medium } \\
\text { Fast and complete }\end{array}$ & $\begin{array}{c}\text { Medium } \\
\text { Slow and incomplete }\end{array}$ & $\begin{array}{c}\text { Medium } \\
\text { speed and } \\
\text { complete }\end{array}$ \\
$\begin{array}{l}\text { Refractory period } \\
\text { Deactivation }\end{array}$ & Long & Medium & Medium & Short & Short & Very long \\
Activation & Moderately fast & Moderately slow & Very slow & Very fast & Slow \\
& Moderately fast & Slow & Medium & Moderately slow & Medium \\
\hline
\end{tabular}

Table 6 Properties conferred by the "second subunit class" of the receptor

\begin{tabular}{llll}
\hline Isoform & $\beta 1$ & $\beta 2$ & $\beta 3$ \\
\hline GABA EC50 & Medium & Medium & Moderate \\
Desensitization & Medium & Medium & Moderately slow \\
Deactivation & & Medium & Moderately slow \\
\hline
\end{tabular}

synaptic cleft during a GABA burst [134, 202], a concentration much higher than the EC50 of any $\mathrm{GABA}_{\mathrm{A}}$ receptor subtype (Tables 2, 3, 4). Low affinity receptors are thus activated by GABA bursts without being activated by background GABA concentration (Fig. 7a), which ensures that receptor activation is dependent on pre-synaptic inputs. The quick activation of most phasic receptors increases the speed at which neuronal networks communicate, and allows the receptors to respond to GABA bursts despite the extremely fast clearance of GABA in the synapse (whose time constant is only $0.3-0.6 \mathrm{~ms}$ ) [134].

The transmission of a strong inhibitory signal requires maximization of charge transfer. This is ensured by the high receptor concentration (there are usually tens to hundreds of receptors per inhibitory synapse) $[56,73]$ and the maintenance of the IPSC for relatively long times [102]. Indeed, the slow or intermediate deactivation of phasic receptors enables IPSCs to last several tens of milliseconds. In addition, slow deactivation is associated with fast and complete desensitization, which explains the common observation of IPSC depression upon high frequency stimulation, a phenomenon termed rundown (Fig. 4a) [203, 204]. This process protects neurons against pathological excessive inhibition in case of defective clearance of GABA, or excessive GABA emission in the synaptic cleft.

Different $\mathrm{GABA}_{\mathrm{A}}$ receptor subtypes can be located at different synapses of the same neuron. This phenomenon enables precise modulation of neurotransmission because identical signals received at different synapses will not induce the same phasic current in the postsynaptic neuron [196, 205, 206]. Several subtypes can even be expressed in the same synapse [207-210]. In such a case, the post-synaptic current triggered by GABA is a composite of the currents mediated by the individual subtypes.

Ternary subtypes ( $\alpha \beta \gamma$ or $\alpha \beta \delta$ ) and $\rho$-containing subtypes are coexpressed at the axon terminals of retinal bipolar cells $[208,210]$ and mediate different types of phasic currents: ternary receptors mediate fast and brief currents, whereas $\rho$-containing receptors mediate long and delayed currents that can be explained by their slow activation and lack of desensitization [211]. Since $\rho$-containing subtypes have the lowest GABA EC50 (Tables 2, 3, 4), it is possible that at low GABA concentration, only the slow and long currents take place. Therefore, the diversity of phasic receptors facilitates complex and diverse responses to GABA inputs in a dose-dependent manner [5, 212]. In retinal bipolar cells, the contribution of different $\mathrm{GABA}_{\mathrm{A}}$ receptor subtypes to the generation of inhibitory currents varies between cell subpopulations $[213,214]$, probably because of differences in

Table 7 Properties conferred by the "third subunit class" of the receptor

\begin{tabular}{|c|c|c|c|c|c|c|}
\hline Isoform & $\gamma 1$ & $\gamma 2 \mathrm{~L}$ & $\gamma 3$ & $\delta$ & $\varepsilon$ & $\pi$ \\
\hline Conductance & Medium & Medium & Medium & Low & Low & Medium \\
\hline GABA EC50 & Medium & $\begin{array}{l}\text { Medium ( } \gamma 2 \mathrm{~L} \text { variant }) \text { or moderate } \\
(\gamma 2 \mathrm{~S} \text { variant })\end{array}$ & Moderate & Low & Medium & Moderate \\
\hline Hill coefficient & Medium & Medium & Medium & Medium & Low & Medium \\
\hline Desensitization & & Complete and moderately fast & & Slow and incomplete & Fast & \\
\hline Deactivation & & Medium & & Moderately fast & & \\
\hline Activation & & Fast & & Slow & & \\
\hline
\end{tabular}


Fig. 6 Effects of spillover on $\mathrm{GABA}_{\mathrm{A}}$ receptor-mediated postsynaptic currents. Phasic activity occurs upon the fixation of GABA by $\mathrm{GABA}_{\mathrm{A}}$ receptors on the post-synaptic neuron. Spillovers from nearby synapses can desensitize part of the receptors and decrease the amplitude of the next IPSC

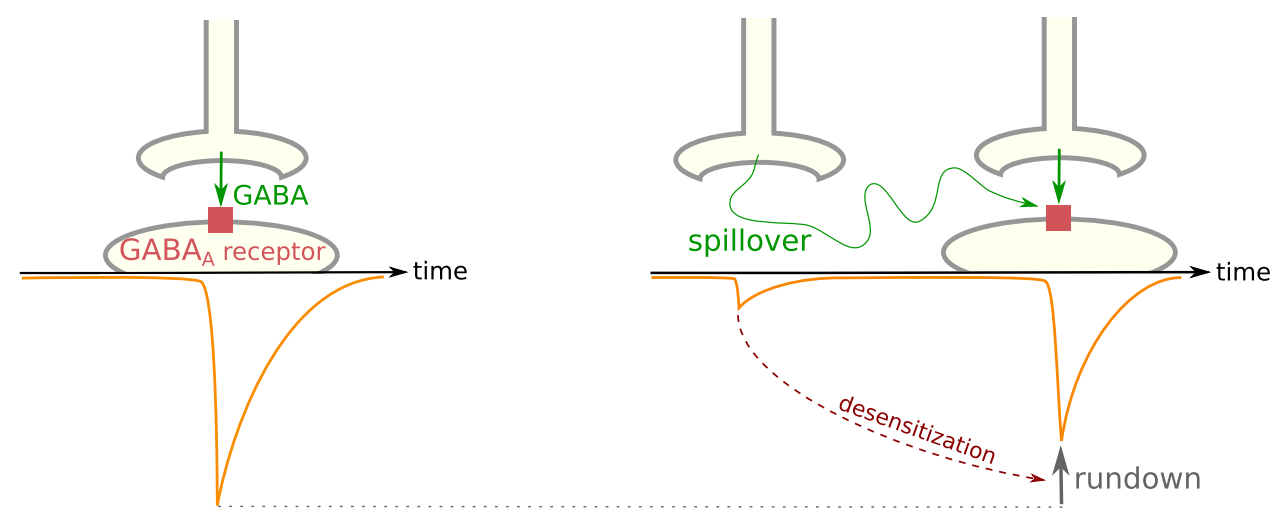

abundance of the considered subtypes. Consequently, the IPSCs follow different times-courses in different cell subpopulations [215], leading to differences in cell function (reviewed in [5]). This exemplifies that the characteristics of an IPSC depend on the $\mathrm{GABA}_{\mathrm{A}}$ receptor subtype by which it is mediated and that different types of neurons can vary in their phasic activity as a consequence of different subtypes expression patterns (reviewed in [216]).

During development, phasic currents are longer and less intense than in the adult brain [56, 73, 200, 217]. Indeed, the $\alpha 1$ and $\alpha 2$ subunits are not yet expressed at high levels and most synaptic receptors belong to the $\alpha 3 \beta \gamma 2$ subtypes, which display very slow deactivation (Tables $2,3,4$ ).

Sometimes, GABA escapes from a synapse (a process termed spillover) and reaches a nearby synapse. The micromolar GABA concentration in the receiving synapse induces a very faint IPSC, and desensitizes a portion of the $\mathrm{GABA}_{\mathrm{A}}$ receptors present there, which enter refractory periods that can last several seconds. If millimolar GABA bursts occur in the synapse before the end of the refractory period, the resulting phasic current will be diminished by rundown (Fig. 6) [131]. Since GABA bursts frequently occur in synapses, the net effect of spillovers is often excitatory despite the faint IPSC they directly induce. Spillovers are rare in physiological conditions in the adult brain since highly efficient GABA uptake systems usually ensure efficient clearance of GABA in synapses; however, these systems can be downregulated [218, 219].

Whether $\mathrm{GABA}_{\mathrm{A}}$ receptor-mediated currents are excitatory or inhibitory depends in certain circumstances on receptor location and timing relative to depolarizing signals $[220,221]$, hence the importance of the brevity and spatial confinement of phasic currents [198]. Phasic currents are brief and often induced at a single synapse, allowing them to regulate neuronal and cerebral activity very finely and to generate a substantial diversity of responses to similar inputs, in part due to $\mathrm{GABA}_{\mathrm{A}}$ receptor subtype diversity. Among other functions, $\mathrm{GABA}_{\mathrm{A}}$ receptor phasic activity is required in the generation of $\theta$ and $\gamma$ frequency network oscillations, under strict temporal control [198].

\section{Tonic activity}

Certain $\mathrm{GABA}_{\mathrm{A}}$ receptors, mostly extrasynaptic, mediate chronic low-amplitude currents termed tonic currents [198]. Their activity is less temporally and spatially restricted than that of phasic receptors [198]. They are involved in longrun (seconds to minutes) modulation of neuronal activity and respond to GABA spillover or to non-synaptic release of GABA. They belong mostly to subtypes containing the $\delta$ subunit and the $\alpha 4, \alpha 5$ or $\alpha 6$ subunits $[64,114,196$, 222 ] or to $\rho$-containing subtypes [62], although certain $\gamma 2$-containing subtypes can mediate tonic currents (reviewed in [201]). The characteristics of tonic activity are related to the electrochemical properties of the $\mathrm{GABA}_{\mathrm{A}}$ receptor subtypes involved [223]: these subtypes display a high affinity to GABA (Tables 2, 3, 4), allowing a response to low extrasynaptic GABA concentration; and a low conductance as well as incomplete desensitization, enabling channel groups to deliver limited but steady currents (Fig. 7b). Furthermore, the amplitude of current mediated by $\delta$-containing receptors at saturating GABA concentrations can be multiplied up to 20 times by the agonist etomidate [109], showing that the maximal open probability in the absence of agonists Pomax of the concerned subtypes is no higher than 5\%, and explaining the low amplitude of the tonic currents they mediate.

$\gamma$-containing subtypes desensitize extensively when exposed to high GABA concentrations, but the low GABA concentrations which elicit tonic activity may not desensitize them to such an extent as to abolish tonic currents [114, 195]. Deactivation does not hamper tonic activity, because GABA presence is maintained over long periods, allowing closed receptors to reopen; deactivation even ensures that tonic currents remain at a low amplitude. Finally, the slow activation of tonic receptors, caused both by low GABA concentrations and the electrophysiological properties of the 
a

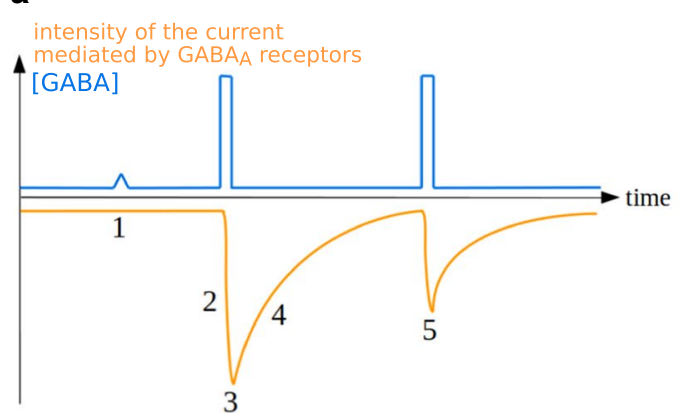

b

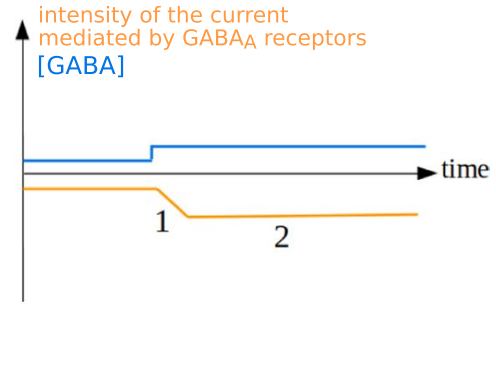

Fig. 7 Comparison of phasic and tonic currents. a Phasic current. 1: due to the high GABA EC50 of most phasic receptors, background GABA transients do not activate $\mathrm{GABA}_{\mathrm{A}}$ receptors. 2: fast activation.

subtypes involved, participates in shaping tonic currents. At subsaturating GABA concentrations, the current peak is truncated, resulting in stable currents reaching a steady state without going through sharp peaks after changes in GABA concentration [112].

Receptors that usually mediate phasic currents can at times display a low-level tonic activity, including in synaptic locations, due to a very low but strictly positive probability of opening at GABA concentrations close to zero [132, 224]. For example, even at standard extracellular GABA concentration, the amplitude of tonic currents through $\alpha 1 \beta 2 \gamma 2 \mathrm{~L}$ can reach $1 \%$ of the amplitude of phasic currents [224]. Moreover, it has been proposed that certain subtypes can mediate both phasic and tonic currents not only depending on their location or on GABA concentration, but also on whether both or only one of their two GABA-binding sites are occupied [175].

Tonic charge transfer can have a significant effect on neuronal communication: it has stronger inhibitory effects than phasic inhibition in certain neuron types such as cerebellar granule cells and hippocampal pyramidal cells $[73,200,222$, 225]. This demonstrates that the steadiness of tonic currents can compensate for their lack of intensity compared to phasic currents in generating a strong response [222].

Tonic activity has been predicted to have different effects than phasic activity on neuronal network activity, notably a decrease of rhythmicity and synchronicity between neurons [226, 227]. At a wider scale, models of cerebellar activity predict that tonic inhibition increases the number of motor patterns that can be stored in the cerebellum [228, 229].

During development, tonic activity is mainly activated by action potential-induced GABA release in the extracellular space [73, 200, 217]; however, non-vesicular and acetylcholine-induced, action potential-independent GABA release plays the major role in tonic inhibition in the adult cerebellum [137, 200]. This developmental transition can be related to the increasing wrapping of synapses by glial
3: high amplitude current peak. 4: slow deactivation. 5: rundown. b Tonic current. 1: slow activation. 2: steady-state, low-amplitude current with limited desensitization

cells [230], which progressively prevents GABA spillover [200]. It is not only the source of tonic currents that varies during development, but also their amplitude. For example, tonic currents are detected in hippocampal pyramidal cells only in embryonic life [231], while they increase over time in cerebellar granule cells [73, 200]. Spatial discrepancies can also be caused by variations in extracellular GABA concentration between brain areas [225].

Tonic currents can modify the information conveyed by neurons [70, 232]. Unlike phasic currents, they do not determine the information conveyed by a single message but rather subtly modulate the information transmitted by the neuron over long time frames encompassing several communication events. Tonic inhibition is a form of regional-scale neuromodulation, offering a negative feedback to periods of intense synaptic activity during which successive spillovers increase the extracellular GABA concentration [198]. The long duration of tonic currents enables them to mitigate the oscillatory patterns often induced by phasic communication [226] and thus to desynchronize the activity of neighbor neurons [227].

Since the various tonic $\mathrm{GABA}_{\mathrm{A}}$ receptor subtypes differ in their EC50, slight increases in GABA extracellular concentration can progressively recruit a new receptor population. It widens the repertoire of potential tonic activity, since limited and finely regulated changes in GABA concentration can lead to the selective activation or inhibition of only part of the receptors mediating tonic currents [225].

Most transporters responsible for the clearance of GABA out of the extracellular space are unable to lower GABA concentration below $0.4 \mu \mathrm{M}$ [233], a concentration higher than the EC50 of several $\alpha 6$-containing subtypes (Tables 2, $3,4)$. Some receptors are thus continually activated and exert a function of leakage channel, as experimentally confirmed in the rat hippocampus [234]. Rather than being involved in the transmission of inhibitory signals, such receptors are believed to regulate membrane resistivity 
[78]. If this hypothesis is correct, these receptors control the time window over which synaptic integration occurs as well as the neuronal gain (the ratio between received and emitted currents), and thus the action potential firing rate [225, 232]. This exemplifies that the functions accomplished by a $\mathrm{GABA}_{\mathrm{A}}$ receptor subtype are determined by its electrophysiology.

\section{Perisynaptic $\mathrm{GABA}_{A}$ receptors}

Perisynaptic $\mathrm{GABA}_{\mathrm{A}}$ receptors are activated by GABA spillover out of the synaptic cleft. They account for the slowcomponent inhibition of biphasic GABA-mediated response [235], a phenomenon in which the GABA released in a synapse first activates phasic post-synaptic receptors, then spills over in the extracellular space and activates perisynaptic receptors. GABA diffuses in a much greater volume in the extracellular space than in the synaptic cleft. Consequently, it reaches perisynaptic receptors with a delay compared to synaptic receptors and at a much lower concentration. Therefore, the biphasic GABA-mediated response consists of a localized, fast and intense phasic current followed by a diffuse, low-level and less cell-specific hyperpolarization. Perisynaptic receptors thus prolong phasic activity. They also take part in tonic inhibition [73] and spillover-mediated heterosynaptic modulation [232], whereby GABA spillover out of a synapse inhibits nearby neurons uninvolved in the considered synapse (reviewed in [236]).

\section{Presynaptic inhibition}

$\mathrm{GABA}_{\mathrm{A}}$ receptors can be found on the axons of certain neuron types, where they sometimes mediate depolarizations, with either inhibitory [237, 238] or excitatory [78, 239] effects on downstream synaptic activity.

In the process of presynaptic inhibition, GABA released at axo-axonic synapses activates $\mathrm{GABA}_{\mathrm{A}}$ receptors on the axon of the receiving neuron and prevents the propagation of synchronous action potentials [240] (Fig. 8). Unlike synaptic and perisynaptic inhibitions [241], presynaptic inhibition requires a precise synchronization of the excitatory signal with the chloride influx mediated by the $\mathrm{GABA}_{\mathrm{A}}$ receptor [198]. However, this does not necessarily imply that the GABA input must be synchronized with the action potentials: indeed, in certain retinal cells where $\rho$-containing subtypes are exclusively located in axons [213], the longlasting signals mediated by these subtypes ensure an efficient presynaptic inhibition which allows a small delay between the inhibitory input and the action potentials.

The functions of presynaptic inhibition remain poorly understood [78]. However, the release of GABA by axons of hippocampal mossy fiber [242, 243] or cerebellar basket and stellar cells [244] suggests that one function of presynaptic

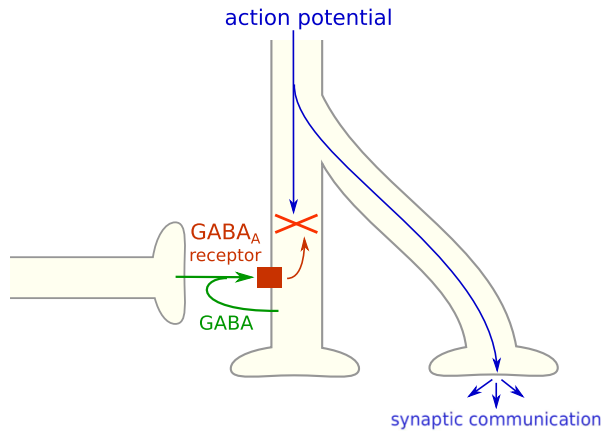

Fig. 8 Presynaptic inhibition of action potentials mediated by $\mathrm{GABA}_{\mathrm{A}}$ receptors. Inhibitory currents mediated by $\mathrm{GABA}_{\mathrm{A}}$ receptors can inhibit simultaneous action potentials, and allow different axonal ramifications to convey different signals

inhibition is self-inhibition and tissular negative feedback on neuronal activity. In addition, presynaptic inhibition enables the axonal ramifications of a neuron to convey different messages if only part of the ramifications receive a presynaptic inhibitory signal (Fig. 8). This mechanism increases the complexity and specificity of neuronal communication [245]. For example, the presynaptic inhibition mediated by $\rho$-containing subtypes in the retina increases the dynamic range of brain responses to light intensity [246].

\section{Control of $\mathrm{GABA}_{A}$ receptor electrophysiology}

$\mathrm{GABA}_{\mathrm{A}}$ receptor electrical activity is determined by GABA concentration and its intrinsic electrophysiological properties, but also by its chemical and cellular environment, sometimes in a subtype-specific manner.

\section{$\mathrm{GABA}_{A}$ receptor control by phosphorylation}

$\mathrm{GABA}_{\mathrm{A}}$ receptors are subject to phosphorylation by several kinases such as protein kinase $\mathrm{A}$ (PKA) and $\mathrm{C}$ (PKC). Phosphorylation by $\mathrm{PKC}$ inhibits $\mathrm{GABA}_{\mathrm{A}}$ receptors, probably by endocytosis [247] or through an inhibition of the non-desensitizing fraction of $\mathrm{GABA}_{\mathrm{A}}$ receptors [248]. Both increases [249, 250] and decreases [147, 251-253] in currents mediated by $\mathrm{GABA}_{\mathrm{A}}$ receptors have been reported upon phosphorylation by PKA, probably because it can simultaneously speed up desensitization while slowing down deactivation $[254,255]$. In the retina, PKA mediates dopaminergic signals which result in a potentiation of $\mathrm{GABA}_{\mathrm{A}}$ receptors through a decrease in GABA EC50 [128]. Phosphorylation may explain the differences in electrophysiology between $\gamma 2 S$ and $\gamma 2 \mathrm{~L}$ containing receptors, since the only difference between these two splice forms is a cytoplasmic insertion of 8 residues in $\gamma 2 \mathrm{~L}$ containing a PKC phosphorylation site [34]. 
Receptors of different neurotransmitters can colocalize at post-synaptic sites and be activated by presynaptic co-release of several neurotransmitters. The simultaneous activation of different postsynaptic receptors often induces a partial occlusion of their respective currents. This crosstalk has been proposed to represent a fast adaptive process in controlling signal transmission [256]. Negative cross-talk was demonstrated between $\mathrm{GABA}_{\mathrm{A}}$ receptors and dopamine receptors [256], P2X receptors [257] and glycine receptors [258]. The inhibition of $\mathrm{GABA}_{\mathrm{A}}$ receptors by glycine receptors depends on phosphatase $2 \mathrm{~B}$ activity, while kinase activity is necessary for recovery of $\mathrm{GABA}_{\mathrm{A}}$ receptors from this inhibition [259].

Glutamate excitatory neurotransmission mediated by NMDA receptors induces calcineurin-dependent $\gamma 2$ subunit dephosphorylation, leading to a reversible and local dispersion of postsynaptic GABA A $_{A}$ receptor clusters [260]. Dispersion lowers receptors' EC50, activation and desensitization times, and slows down their deactivation [261-263]. Consequently, receptors transition from synaptic phasic activity to extrasynaptic tonic activity upon dephosphorylation.

\section{Voltage dependency}

Although $\mathrm{GABA}_{\mathrm{A}}$ receptors are generally voltage-independent, a few subtypes are voltage-sensitive in rare situations $[123,240,264]$. Voltage seems to affect current peak amplitude but not kinetic properties (desensitization and deactivation) of the $\alpha 1 \beta 3 \delta, \alpha 5 \beta 3 \pi$ and $\rho 1$ subtypes $[106,123,191$, $192]$, unlike the $\alpha 6 \beta 3 \delta$ subtype whose kinetic properties are affected but not other parameters [123]. Voltage dependency can also be observed in channels that are rare or never found in vivo, such as $\alpha 1 \beta 3$ or $\alpha 6 \beta 3$ [123].

\section{Ionic modulation}

$\mathrm{GABA}_{\mathrm{A}}$ receptors are sensitive to ionic modulation: a change in the concentration of certain ions, in either the extracellular or the cytosolic compartment, can modify their activity. The nature or extent of the modulation is subtypespecific (Fig. 9).

Extracellular $\mathrm{Ca}^{2+}$ does not affect the activity of ternary receptors [87, 265], but it increases the amplitude of currents mediated by $\rho$-containing subtypes [266]. Intracellular $\mathrm{Ca}^{2+}$ has varying effects on many subtypes, depending on its origin and concentration. $\mathrm{Ca}^{2+}$ coming from the extracellular space does not affect $\mathrm{GABA}_{\mathrm{A}}$ receptor opening [267], whereas $\mathrm{Ca}^{2+}$ originating from intracellular compartments activates $\mathrm{GABA}_{\mathrm{A}}$ receptors at low concentrations, but inhibits it at high concentrations [268, 269]. This may be a consequence of receptor phosphorylation by PKC [248] or dephosphorylation by calcineurin [260], because these enzymes are activated by intracellular calcium. $\mathrm{Ca}^{2+}$ control

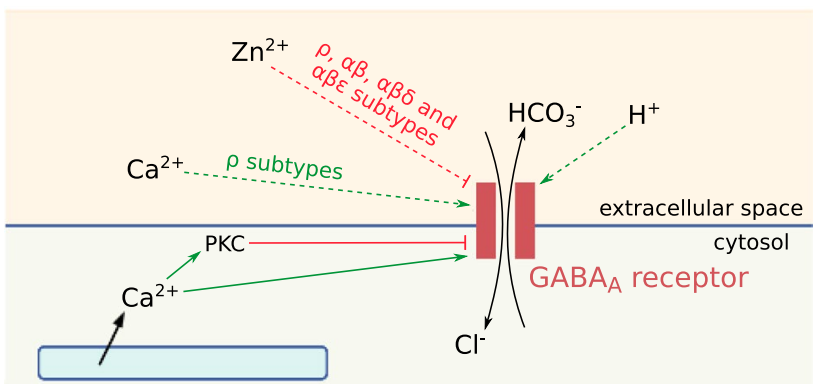

endoplasmic reticulum or mitochondria

Fig. 9 Ionic modulation of the $\mathrm{GABA}_{\mathrm{A}}$ receptor. Ion flows are represented with black arrows, activation with green arrows and inhibition with red arrows. Dashed lines indicate subtype specificity

of $\mathrm{GABA}_{\mathrm{A}}$ receptors is involved in the long-run (seconds to minutes) modulation of neuronal activity [268].

Extracellular $\mathrm{Zn}^{2+}$ is released during synaptic activity by numerous neurons, particularly in the limbic and neocortical regions [270] and during development. It decreases the opening frequency of certain $\mathrm{GABA}_{\mathrm{A}}$ receptor subtypes [271] (reviewed in [4]). $\alpha \beta$ receptors are up to 3400 -fold more sensitive to $\mathrm{Zn}^{2+}$ than $\alpha \beta \gamma$ and $\alpha \beta \delta$ receptors [113, 272], while $\rho$ [266], $\alpha \beta \pi$ [191] and $\alpha \beta \varepsilon[126,171]$ subtypes have an intermediate sensitivity. In addition, $\alpha 1$ confers a higher zinc sensitivity than the other $\alpha$ subunits $[124,126$, $171,182,189,273]$. The discrepancy in sensitivity between $\alpha \beta \gamma$ and $\alpha \beta$ subtypes is explained by the position of the $\mathrm{Zn}^{2+}$ binding sites in the receptor (two between $\alpha$ and $\beta$ subunits and one in the ion pore), which are disturbed by $\gamma$ subunits $[182,274]$. Additionally, $\alpha \beta$ subtypes comprised of two $\alpha$ and three $\beta$ subunits contain a third zinc-binding site at the $\beta-\beta$ interface, explaining their higher sensitivity compared with $\alpha \beta \gamma$ subtypes and the very rare $\alpha \beta$ subtypes containing three $\alpha$ and two $\beta$ subunits [129]. Zinc increases the EC50 of $\alpha 1 \beta 1 \delta$ but not $\alpha 1 \beta 1$, and the Hill coefficient of $\alpha 1 \beta 1$ while it decreases the Hill coefficient of $\alpha 1 \beta 1 \delta$ [273]. $\mathrm{Zn}^{2+}$ sensitivity displays very similar characteristics in vivo and in vitro (reviewed in [5]). $\mathrm{Zn}^{2+}$ may take part in the control of tonic currents in hippocampal pyramidal neurons, where up to $10 \%$ of extrasynaptic $\mathrm{GABA}_{\mathrm{A}}$ receptors may belong to $\alpha \beta$ subtypes [180].

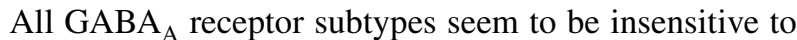
intracellular $\mathrm{pH}$ [275] (reviewed in [4]), but certain subtypes are sensitive to extracellular $\mathrm{pH}$ because of their two extracellular proton-binding sites $[170,275]$. Conductance is negatively correlated with extracellular $\mathrm{pH}$ for $\alpha 1 \beta 1, \alpha 1 \beta 2 \gamma 2$ and $\alpha 1 \beta 1 \delta$ [170, 276], and positively for $\rho$ subtypes [277, 278], while $\alpha 1 \beta 1 \gamma 2 \mathrm{~S}$ is $\mathrm{pH}$-insensitive [170] and the curves of $\alpha 1 \beta 1 \gamma 2 S \delta, \alpha 4 \beta 3 \gamma 2, \alpha 4 \beta 3 \delta$ and $\alpha 1 \beta 2 \gamma 2 S$ conductance as a function of extracellular $\mathrm{pH}$ are bell-shaped [73, 170]. Extracellular protons slow the deactivation of the $\alpha 1 \beta 3 \delta$ subtype 
and increase its opening probability in the absence of GABA without affecting its desensitization, resulting in an increase of currents at low $\mathrm{pH}$ [181]. On the contrary, $\alpha 1 \beta 2 \gamma 2$ desensitizes less and slower at low $\mathrm{pH}$ [276], while its activation is slowed, and deactivation is shifted toward its slow component. GABA receptor inhibition at high $\mathrm{pH}$ is explained by a faster closure of the channel [279].

In vivo, $\mathrm{GABA}_{\mathrm{A}}$ channel charge transfer is generally negatively correlated with extracellular pH [170, 280]. During synaptic transmission, a transient acidosis of the synaptic cleft is followed by a durable increase in $\mathrm{pH}$ [281]. This phenomenon synergizes with the concomitant variations of GABA concentration and helps to induce a fast and massive opening of $\mathrm{GABA}_{\mathrm{A}}$ receptors during the first milliseconds of synaptic transmission, followed by the progressive closure of the channels when protons and GABA are cleared from the synaptic cleft.

NMDA, the glutamate receptor mediating most of the excitatory signals in the central nervous system, is inhibited by low $\mathrm{pH}$ [282]. Thus, the opposite effects of $\mathrm{pH}$ on the inhibitory $\mathrm{GABA}_{\mathrm{A}}$ receptor and the excitatory NMDA receptor may explain why neuronal activity and excitability increase with extracellular $\mathrm{pH}$ [283]. High regional electrical activity elicits an acidosis: the $\mathrm{pH}$-sensitivity of $\mathrm{GABA}_{\mathrm{A}}$ receptor and NMDA receptor thus creates a negative feedback against hyperactivity. This process relies notably on tonic currents mediated by $\delta$-containing receptors [181]. Other $\mathrm{pH}$ regulation processes can also modulate neurone activity through $\mathrm{GABA}_{\mathrm{A}}$ receptors [280]. Extracellular $\mathrm{pH}$ can itself be modified by bicarbonate transport across $\mathrm{GABA}_{\mathrm{A}}$ receptors [284], making them broadcasters of neuromodulatory signals in addition to their function of chloride channel.

Furthermore, acidity displays protective effects against $\mathrm{Zn}^{2+}$ inhibition in $\alpha 1 \beta 1$ receptors [273], showing that the different types of ionic modulation to which $\mathrm{GABA}_{\mathrm{A}}$ receptors are submitted are not independent.

The ionic modulation of the $\mathrm{GABA}_{\mathrm{A}}$ receptor is involved in the long-term depression or potentiation of inhibitory currents characteristic of neuronal plasticity, and may play a role in hypomagnesia-induced hyperexcitability [285], anoxic and ischaemic conditions [286] or epileptogenesis [287].

\section{Conclusion}

$\mathrm{GABA}_{\mathrm{A}}$ receptors are highly complex and are able to generate a vast repertoire of electric responses to different inputs under the control of various types of regulations. Their influence on cellular electric activity at different scales of time and space can to a great extent be predicted from the structural and electrophysiological properties of the different subtypes, whose diversity provides additional modularity, robustness and specialization to the $\mathrm{GABA}_{\mathrm{A}}$ receptor system.

$\mathrm{GABA}_{\mathrm{A}}$ receptor agonists and antagonists are increasingly used in medicine to treat various diseases, from epilepsy to insomnia and others. Improved knowledge of the electrophysiology, pharmacology and expression patterns of $\mathrm{GABA}_{\mathrm{A}}$ receptor subtypes has led to the development of subtype-specific drugs that limit side effects. Further studies on $\mathrm{GABA}_{\mathrm{A}}$ receptor electrophysiology are warranted in order to develop new treatments, particularly in the fields of $\mathrm{GABA}_{\mathrm{A}}$ receptors structure-function relationships, interactions with intracellular proteins, and electrical properties of lesser-known subtypes such as those containing $\pi$ or $\theta$ subunits.

Acknowledgements We are grateful to Thibault Pébrier ${ }^{1}$, Philibert Courau $^{1}$ and María Castro Scherianz ${ }^{1}$ for their helpful review and comments of this article. 1 École Normale Supérieure de Paris, Biology department, PSL research university, 45 rue d'Ulm 75005 Paris, France

Author contributions ES: conceptualization, data collection, curation and analysis, draft writing, manuscript review. DL: manuscript review. PL: supervision, manuscript review.

Funding Open Access funding enabled and organized by Projekt DEAL.

Data availability All data relevant to this review is included in the text, references and figs.

Code availability Not applicable.

\section{Declarations}

Conflict of interest None.

Ethics approval Not applicable.

Consent to participate Not applicable.

Consent for publication Not applicable.

Open Access This article is licensed under a Creative Commons Attribution 4.0 International License, which permits use, sharing, adaptation, distribution and reproduction in any medium or format, as long as you give appropriate credit to the original author(s) and the source, provide a link to the Creative Commons licence, and indicate if changes were made. The images or other third party material in this article are included in the article's Creative Commons licence, unless indicated otherwise in a credit line to the material. If material is not included in the article's Creative Commons licence and your intended use is not permitted by statutory regulation or exceeds the permitted use, you will need to obtain permission directly from the copyright holder. To view a copy of this licence, visit http://creativecommons.org/licenses/by/4.0/. 


\section{References}

1. Bloom FE, Iversen LL (1971) Localizing 3H-GABA in nerve terminals of rat cerebral cortex by electron microscopic autoradiography. Nature 229:628-630. https://doi.org/10.1038/22962 $8 \mathrm{a} 0$

2. Young AB, Chu D (1990) Distribution of GABAA and GABAB receptors in mammalian brain: potential targets for drug development. Drug Dev Res 21:161-167. https://doi.org/10.1002/ddr. 430210303

3. Bormann J, Hamill OP, Sakmann B (1987) Mechanism of anion permeation through channels gated by glycine and gammaaminobutyric acid in mouse cultured spinal neurones. J Physiol 385:243-286. https://doi.org/10.1113/jphysiol.1987.sp016493

4. Kaila K (1994) Ionic basis of GABAA receptor channel function in the nervous system. Prog Neurobiol 42:489-537

5. Zhang D, Pan Z-H, Awobuluyi M, Lipton SA (2001) Structure and function of GABAC receptors: a comparison of native versus recombinant receptors. Trends Pharmacol Sci 22:121-132. https://doi.org/10.1016/S0165-6147(00)01625-4

6. Olsen RW, Sieghart W (2008) International Union of Pharmacology. LXX. Subtypes of $\gamma$-aminobutyric acid a receptors: classification on the basis of subunit composition, pharmacology, and function. Update Pharmacol Rev 60:243-260. https://doi.org/10. 1124/pr.108.00505

7. Harvey RJ, Vreugdenhil E, Zaman SH et al (1991) Sequence of a functional invertebrate GABAA receptor subunit which can form a chimeric receptor with a vertebrate alpha subunit. EMBO J 10:3239-3245. https://doi.org/10.1002/j.1460-2075.1991.tb048 87. $\mathrm{x}$

8. Olsen RW, Tobin AJ (1990) Molecular biology of GABA receptors. FASEB J 4:1469-1480. https://doi.org/10.1096/fasebj.4.5. 2155149

9. Sieghart W (2000) Unraveling the function of GABAA receptor subtypes. Trends Pharmacol Sci 21:411-413. https://doi.org/10. 1016/S0165-6147(00)01564-9

10. Olsen RW, Sieghart W (2009) GABAA receptors: subtypes provide diversity of function and pharmacology. Neuropharmacology 56:141-148. https://doi.org/10.1016/j.neuropharm.2008.07. 045

11. Rabow LE, Russek SJ, Farb DH (1995) From ion currents to genomic analysis: recent advances in GABAA receptor research. Synapse 21:189-274. https://doi.org/10.1002/syn.890210302

12. Sieghart W, Sperk G (2002) Subunit composition, distribution and function of GABA-A receptor subtypes. CTMC 2:795-816. https://doi.org/10.2174/1568026023393507

13. Hevers W, Lüddens $H$ (1998) The diversity of GABAA receptors. Mol Neurobiol 18:35-86

14. Carter CR, Kozuska JL, Dunn SM (2010) Insights into the structure and pharmacology of $\mathrm{GABA}_{\mathrm{A}}$ receptors. Future Med Chem 2:859-875. https://doi.org/10.4155/fmc. 10.178

15. Chua HC, Chebib M (2017) GABA A receptors and the diversity in their structure and pharmacology. Advances in pharmacology. Elsevier, pp 1-34

16. Hanrahan JR, Chebib M, Johnston GAR (2011) Flavonoid modulation of GABAA receptors: flavonoids and GABAA receptors. Br J Pharmacol 163:234-245. https://doi.org/10.1111/j.14765381.2011.01228.x

17. D'Hulst C, Atack JR, Kooy RF (2009) The complexity of the GABAA receptor shapes unique pharmacological profiles. Drug Discov Today 14:866-875. https://doi.org/10.1016/j.drudis.2009. 06.009

18. Johnston $\mathrm{G}$ (2005) GABAA receptor channel pharmacology. CPD 11:1867-1885. https://doi.org/10.2174/1381612054021024
19. Johnston G (2002) Medicinal chemistry and molecular pharmacology of GABA-C receptors. CTMC 2:903-913. https://doi.org/ $10.2174 / 1568026023393453$

20. Möhler H (2001) GABAA-receptor subtypes: a new pharmacology. Curr Opin Pharmacol 1:22-25. https://doi.org/10.1016/ S1471-4892(01)00008-X

21. McCall MA, Lukasiewicz PD, Gregg RG, Peachey NS (2002) Elimination of the rho1 subunit abolishes GABAC receptor expression and alters visual processing in the mouse retina. $\mathbf{J}$ Neurosci 22:4163-4174

22. Uusi-Oukari M, Korpi ER (2010) Regulation of GABAA receptor subunit expression by pharmacological agents. Pharmacol Rev 62:97-135. https://doi.org/10.1124/pr.109.002063

23. Lévi S, Chesnoy-Marchais D, Sieghart W, Triller A (1999) Synaptic control of glycine and $\mathrm{GABA}_{\mathrm{A}}$ receptors and gephyrin expression in cultured motoneurons. J Neurosci 19:7434-7449. https://doi.org/10.1523/JNEUROSCI.19-17-07434.1999

24. Kittler JT, Moss SJ (2003) Modulation of GABAA receptor activity by phosphorylation and receptor trafficking: implications for the efficacy of synaptic inhibition. Curr Opin Neurobiol 13:341-347. https://doi.org/10.1016/S0959-4388(03) 00064-3

25. Lüscher B, Keller CA (2004) Regulation of GABAA receptor trafficking, channel activity, and functional plasticity of inhibitory synapses. Pharmacol Ther 102:195-221. https://doi.org/10. 1016/j.pharmthera.2004.04.003

26. v. Blankenfeld G, Kettenmann H (1991) Glutamate and GABA receptors in vertebrate glial cells. Mol Neurobiol 5:31-43. https://doi.org/10.1007/BF02935611

27. Wang Q, Prud'homme G, Wan Y (2015) GABAergic system in the endocrine pancreas: a new target for diabetes treatment. DMSO 8:79-87. https://doi.org/10.2147/DMSO.S50642

28. Young SZ, Bordey A (2009) GABA's control of stem and cancer cell proliferation in adult neural and peripheral niches. Physiology 24:171-185. https://doi.org/10.1152/physiol.00002.2009

29. Bjurstöm H, Wang J, Ericsson I et al (2008) GABA, a natural immunomodulator of T lymphocytes. J Neuroimmunol 205:4450. https://doi.org/10.1016/j.jneuroim.2008.08.017

30. Egawa K, Fukuda A (2013) Pathophysiological power of improper tonic GABAA conductances in mature and immature models. Front Neural Circuits. https://doi.org/10.3389/fncir. 2013.00170

31. Addolorato G, Leggio L, Hopf FW et al (2012) Novel therapeutic strategies for alcohol and drug addiction: focus on GABA, ion channels and transcranial magnetic stimulation. Neuropsychopharmacol 37:163-177. https://doi.org/10.1038/npp.2011.216

32. Macdonald RL, Kang J-Q, Gallagher MJ (2010) Mutations in GABAA receptor subunits associated with genetic epilepsies: GABAA receptor subunits associated with genetic epilepsies. J Physiol 588:1861-1869. https://doi.org/10.1113/jphysiol.2010. 186999

33. Bonnert TP, Mckernan RM, Farrar S et al (1999) theta, a novel gamma-aminobutyric acid type A receptor subunit. Proc Natl Acad Sci USA 96:9891-9896

34. Simon J, Wakimoto H, Fujita N et al (2004) Analysis of the set of GABAA receptor genes in the human genome. J Biol Chem 279:41422-41435. https://doi.org/10.1074/jbc.M401354200

35. Whiting P, Mckernan RM, Iversen LL (1990) Another mechanism for creating diversity in gamma-aminobutyrate type A receptors: RNA splicing directs expression of two forms of gamma2 subunit, one of which contains a protein kinase $\mathrm{C}$ phosphorylation site. Proc Natl Acad Sci USA 87:9966-9970

36. Macdonald RL, Olsen RW (1994) GABA receptor channels. Annu Rev Neurosci 17:569-602. https://doi.org/10.1146/annur ev.ne.17.030194.003033 
37. Darlison MG (1992) Invertebrate GABA and glutamate receptors: molecular biology reveals predictable structures but some unusual pharmacologies. Trends Neurosci 15:469-474. https:// doi.org/10.1016/0166-2236(92)90091-L

38. Jones A, Korpi ER, McKernan RM et al (1997) Ligand-gated ion channel subunit partnerships: GABAA receptor alpha6 subunit gene inactivation inhibits delta subunit expression. J Neurosci 17:1350-1362

39. Mihalek RM, Banerjee PK, Korpi ER et al (1999) Attenuated sensitivity to neuroactive steroids in gamma-aminobutyrate type A receptor delta subunit knockout mice. Proc Natl Acad Sci USA 96:12905-12910

40. Sur C, Wafford KA, Reynolds DS et al (2001) Loss of the Major $\mathrm{GABA}_{\mathrm{A}}$ receptor subtype in the brain is not lethal in mice. $\mathrm{J}$ Neurosci 21:3409-3418. https://doi.org/10.1523/JNEUROSCI. 21-10-03409.2001

41. Vollenweider I, Smith KS, Keist R, Rudolph U (2011) Antidepressant-like properties of $\alpha 2$-containing GABAA receptors. Behav Brain Res 217:77-80. https://doi.org/10.1016/j.bbr.2010. 10.009

42. Culiat CT, Rinchik EM (1994) Phenotypic consequences of deletion of the gamma3, alpha5, or beta3 subunit of the type A gamma-aminobutyric acid receptor in mice. Proc Natl Acad Sci USA 91:2815-2818

43. Amundarain MJ, Ribeiro RP, Costabel MD, Giorgetti A (2019) $\mathrm{GABA}_{\mathrm{A}}$ receptor family: overview on structural characterization. Future Med Chem 11:229-245. https://doi.org/10.4155/ fmc-2018-0336

44. Scott S, Aricescu AR (2019) A structural perspective on GABAA receptor pharmacology. Curr Opin Struct Biol 54:189-197. https://doi.org/10.1016/j.sbi.2019.03.023

45. Masiulis S, Desai R, Uchański T et al (2019) GABAA receptor signalling mechanisms revealed by structural pharmacology. Nature 565:454-459. https://doi.org/10.1038/s41586-018-0832-5

46. Rossokhin AV (2017) Homology modeling of the transmembrane domain of the GABAA receptor. Biophysics 62:708-716. https:// doi.org/10.1134/S0006350917050190

47. Chang Y, Weiss DS (1999) Allosteric activation mechanism of the alpha1beta2gamma2 gamma-aminobutyric acid type A receptor revealed by mutation of the conserved M2 leucine. Biophys J 77:2542-2551

48. Jechlinger M, Pelz R, Tretter V et al (1998) Subunit composition and quantitative importance of hetero-oligomeric receptors: GABAA receptors containing alpha6 subunits. J Neurosci 18:2449-2457

49. Mertens S, Benke D, MohlerS H (1993) GABAA receptor populations with novel subunit combinations and drug binding profiles identified in brain by alpha5- and delta subunit-specific immunopurification. J Biol Chem 268:5965-5973

50. Lüddens H, Killisch I, Seeburg PH (1991) More than one alpha variant may exist in a $\mathrm{Gaba}_{\mathrm{A}}$ /benzodiazepine receptor complex. J Recept Res 11:535-551. https://doi.org/10.3109/1079989910 9066426

51. Li M, Blas ALD (1997) Coexistence of two beta subunit isoforms in the same gamma-aminobutyric acid type A receptor. J Biol Chem 272:16564-16569

52. Duggan MJ, Pollard S, Stephenson FA (1991) Immunoaffinity purification of GABAA receptor alpha-subunit iso-oligomers. Demonstration of receptor populations containing alpha 1 alpha 2, alpha 1 alpha 3 , and alpha 2 alpha 3 subunit pairs. J Biol Chem 266:24778-24784

53. Zezula J, Sieghart W (1991) Isolation of type I and type II GABAA-benzodiazepine receptors by immunoaffinity chromatography. FEBS Lett 284:15-18. https://doi.org/10.1016/00145793(91)80750-W
54. Bormann J (2000) The 'ABC' of GABA receptors. Trends Pharmacol Sci 21:16-19. https://doi.org/10.1016/S0165-6147(99) 01413-3

55. Backus K, Arigoni M, Drescher U et al (1993) Stoichiometry of a recombinant GABAA receptor deduced from mutation-induced rectification. NeuroReport 5:285-288

56. Brickley SG, Cull-Candy SG, Farrant M (1999) Single-channel properties of synaptic and extrasynaptic $\mathrm{GABA}_{\mathrm{A}}$ receptors suggest differential targeting of receptor subtypes. J Neurosci 19:2960-2973. https://doi.org/10.1523/JNEUROSCI.19-0802960.1999

57. Gunther U, Benson J, Benke D et al (1995) Benzodiazepineinsensitive mice generated by targeted disruption of the y2 subunit gene of y-aminobutyric acid type A receptors. Proc Natl Acad Sci USA 92:7749-7753

58. Tretter V, Hauer B, Nusser Z et al (2001) Targeted disruption of the GABAA receptor $\delta$ subunit gene leads to an up-regulation of $\gamma 2$ subunit-containing receptors in cerebellar granule cells. J Biol Chem 276:10532-10538. https://doi.org/10.1074/jbc. M011054200

59. Enz R, Cutting GR (1998) Molecular composition of GABAC receptors. Vis Res 38:1431-1441. https://doi.org/10.1016/S00426989(97)00277-0

60. Cutting GR, Donovan DM, Shimada S et al (1991) Cloning of the y-aminobutyric acid (GABA) P1 cDNA: a GABA receptor subunit highly expressed in the retina. Proc Natl Acad Sci USA 88:2673-2677

61. Milligan CJ (2004) Evidence for inhibition mediated by coassembly of GABAA and GABAC receptor subunits in native central neurons. J Neurosci 24:7241-7250. https://doi.org/10.1523/ JNEUROSCI.1979-04.2004

62. Harvey VL, Duguid IC, Krasel C, Stephens GJ (2006) Evidence that GABA $\rho$ subunits contribute to functional ionotropic GABA receptors in mouse cerebellar Purkinje cells: ionotropic GABA receptors in Purkinje cells. J Physiol 577:127-139. https://doi. org/10.1113/jphysiol.2006.112482

63. Tyndale F, Hales G (1994) Distinctive patterns of GABA, receptor subunit mRNAs in 13 cell lines. J Neurosci 14:5417-5428

64. Laurie DJ, Seeburg PH, Wisden W (1992) The distribution of 13 GABA, receptor subunit mRNAs in the rat brain. II. Olfactory bulb and cerebellum. J Neurosci 12:1063-1076

65. Rudolph U, Knoflach F (2011) Beyond classical benzodiazepines: novel therapeutic potential of GABAA receptor subtypes. Nat Rev Drug Discov 10:685-697. https://doi.org/10.1038/nrd35 02

66. Whiting PJ (2003) GABA-A receptor subtypes in the brain: a paradigm for CNS drug discovery? Drug Discov Today 8:445-450. https://doi.org/10.1016/S1359-6446(03)02703-X

67. Thompson SM, Deisz RA, Prince DA (1988) Outward chloride/ cation co-transport in mammalian cortical neurons. Neurosci Lett 89:49-54. https://doi.org/10.1016/0304-3940(88)90479-X

68. Kaila K, Voipio J, Paalasmaa P et al (1993) The role of bicarbonate in GABAA receptor-mediated IPSPs of rat neocortical neurones. J Physiol 464:273-289. https://doi.org/10.1113/jphys iol.1993.sp019634

69. Chen G, Trombley PQ, van den Pol AN (1996) Excitatory actions of GABA in developing rat hypothalamic neurones. J Physiol 494:451-464. https://doi.org/10.1113/jphysiol.1996.sp021505

70. Rivera C, Voipio J, Payne JA et al (1999) The K+/Cl- co-transporter $\mathrm{KCC} 2$ renders GABA hyperpolarizing during neuronal maturation. Nature 397:251-255

71. Serafini R, Valeyev AY, Barker JL, Poulter MO (1995) Depolarizing GABA-activated $\mathrm{Cl}-$ channels in embryonic rat spinal and olfactory bulb cells. J Physiol 488:371-386. https://doi.org/10. 1113/jphysiol.1995.sp020973 
72. Cherubini E, Gaiarsa JL, Ben-Aft Y (1991) GABA: an excitatory transmitter in early postnatal life. TINS 14:515-519

73. Brickley SG, Cull-Candy SG, Farrant M (1996) Development of a tonic form of synaptic inhibition in rat cerebellar granule cells resulting from persistent activation of GABAA receptors. J Physiol 497:753-759. https://doi.org/10.1113/jphysiol.1996. sp021806

74. Michelson H, Wong R (1991) Excitatory synaptic responses mediated by GABAA receptors in the hippocampus. Science 253:1420-1423. https://doi.org/10.1126/science.1654594

75. Glykys J, Staley KJ (2016) Developmental decrease of neuronal chloride concentration is independent of trauma in thalamocortical brain slices. PLoS ONE 11:e0158012. https://doi.org/10. 1371/journal.pone.0158012

76. Staley KJ, Mody I (1992) Shunting of excitatory input to dentate gyrus granule cells by a depolarizing GABAA receptor-mediated postsynaptic conductance. J Neurophysiol 68:197-212. https:// doi.org/10.1152/jn.1992.68.1.197

77. Graham B, Redman S (1994) A simulation of action potentials in synaptic boutons during presynaptic inhibition. J Neurophysiol 71:538-549. https://doi.org/10.1152/jn.1994.71.2.538

78. Kullmann DM, Ruiz A, Rusakov DM et al (2005) Presynaptic, extrasynaptic and axonal GABAA receptors in the CNS: where and why? Prog Biophys Mol Biol 87:33-46. https://doi.org/10. 1016/j.pbiomolbio.2004.06.003

79. Verdier D, Lund JP, Kolta A (2003) GABAergic control of action potential propagation along axonal branches of mammalian sensory neurons. J Neurosci 23:2002-2007. https://doi.org/10.1523/ JNEUROSCI.23-06-02002.2003

80. Chavas J, Forero ME, Collin T et al (2004) Osmotic tension as a possible link between GABAA receptor activation and intracellular calcium elevation. Neuron 44:701-713. https://doi.org/10. 1016/j.neuron.2004.11.002

81. Llinás R, Mühlethaler M (1988) Electrophysiology of guineapig cerebellar nuclear cells in the in vitro brain stem-cerebellar preparation. J Physiol 404:241-258. https://doi.org/10.1113/ jphysiol.1988.sp017288

82. Owens DF, Kriegstein AR (2002) Is there more to GABA than synaptic inhibition? Nat Rev Neurosci 3:715-727. https://doi. org/10.1038/nrn919

83. Barbin G, Pollard H, Gaïarsa JL, Ben-Ari Y (1993) Involvement of GABAA receptors in the outgrowth of cultured hippocampal neurons. Neurosci Lett 152:150-154. https://doi.org/10.1016/ 0304-3940(93)90505-F

84. Meier J, Akyeli J, Kirischuk S, Grantyn R (2003) GABAA receptor activity and PKC control inhibitory synaptogenesis in CNS tissue slices. Mol Cell Neurosci 23:600-613. https://doi.org/10. 1016/S1044-7431(03)00079-4

85. Behar T, Schaffner A, Colton C et al (1994) GABA-induced chemokinesis and NGF-induced chemotaxis of embryonic spinal cord neurons. J Neurosci 14:29-38. https://doi.org/10.1523/ JNEUROSCI.14-01-00029.1994

86. Mount TJ, Dreyfus F, Black IB (1993) Purkinje cell survival is differentially regulated by metabotropic and lonotropic excitatory amino acid receptors. J Neurosci 13:3173-3179

87. Takeuchi A, Takeuchi N (1971) Anion interaction at the inhibitory post-synaptic membrane of the crayfish neuromuscular junction. J Physiol 212:337-351. https://doi.org/10.1113/jphys iol.1971.sp009328

88. Voipio J, Kaila K (2000) GABAergic excitation and K+-mediated volume transmission in the hippocampus. Progress in brain research. Elsevier, pp 329-338

89. Barker JL, Ransom BR (1978) Amino acid pharmacology of mammalian central neurones grown in tissue culture. J Physiol 280:331-354. https://doi.org/10.1113/jphysiol.1978.sp012387
90. Kim D-Y, Fenoglio K, Kerrigan J, Rho J (2009) Bicarbonate contributes to GABAA receptor-mediated neuronal excitation in surgically resected human hypothalamic hamartomas. Epilepsy Res 83:89-93. https://doi.org/10.1016/j.epilpesyres.2008.09.008

91. Staley KJ, Proctor WR (1999) Modulation of mammalian dendritic GABAA receptor function by the kinetics of $\mathrm{Cl}-$ and $\mathrm{HCO}_{3}$ - transport. J Physiol 519:693-712. https://doi.org/10. 1111/j.1469-7793.1999.0693n.x

92. Staley K, Soldo B, Proctor W (1995) Ionic mechanisms of neuronal excitation by inhibitory GABAA receptors. Science 269:977-981. https://doi.org/10.1126/science.7638623

93. Bianchi MT, Song L, Zhang H, Macdonald RL (2002) Two different mechanisms of disinhibition produced by GABAA receptor mutations linked to epilepsy in humans. J Neurosci 22:53215327. https://doi.org/10.1523/JNEUROSCI.22-13-05321.2002

94. Huntsman MM, Porcello DM, Homanics GE et al (2000) Reciprocal inhibitory connections regulate the spatiotemporal properties of intrathalamic oscillations. J Neurosci 20:1735-1745. https://doi.org/10.1523/JNEUROSCI.20-05-01735.2000

95. Whittington MA, Traub RD, Jefferys JGR (1995) Synchronized oscillations in interneuron networks driven by metabotropic glutamate receptor activation. Nature 373:612-615. https://doi.org/ $10.1038 / 373612 \mathrm{a} 0$

96. Steinbach JH, Akk G (2019) Applying the Monod-WymanChangeux allosteric activation model to pseudo-steady-state responses from $\mathrm{GABA}_{\mathrm{A}}$ receptors. Mol Pharmacol 95:106-119. https://doi.org/10.1124/mol.118.113787

97. Akk G, Shin DJ, Germann AL, Steinbach JH (2018) GABA type A receptor activation in the allosteric coagonist model framework: relationship between $\mathrm{EC}_{50}$ and basal activity. Mol Pharmacol 93:90-100. https://doi.org/10.1124/mol.117.110569

98. Ruesch D, Neumann E, Wulf H, Forman SA (2012) An allosteric coagonist model for propofol effects on $\alpha 1 \beta 2 \gamma 2 \mathrm{~L} \gamma$-aminobutyric acid type A receptors. Anesthesiology 116:47-55. https://doi.org/ 10.1097/ALN.0b013e31823d0c36

99. Gielen MC, Lumb MJ, Smart TG (2012) Benzodiazepines modulate GABAA receptors by regulating the preactivation step after GABA binding. J Neurosci 32:5707-5715. https://doi.org/10. 1523/JNEUROSCI.5663-11.2012

100. Lavoie AM, Tingey JJ, Harrison NL et al (1997) Activation and deactivation rates of recombinant $\mathrm{GABA}(\mathrm{A})$ receptor channels are dependent on alpha-subunit isoform. Biophys J 73:2518 2526. https://doi.org/10.1016/S0006-3495(97)78280-8

101. Bianchi MT, Macdonald RL (2002) Slow phases of GABA receptor desensitization: structural determinants and possible relevance for synaptic function. J Physiol 544:3-18. https://doi. org/10.1113/jphysiol.2002.020255

102. Jones MV, Westbrook GL (1995) Desensitized states prolong GABAA channel responses to brief agonist pulses. Neuron 15:181-191. https://doi.org/10.1016/0896-6273(95)90075-6

103. McClellan AML, Twyman RE (1999) Receptor system response kinetics reveal functional subtypes of native murine and recombinant human GABAA receptors. J Physiol 515:711-727. https:// doi.org/10.1111/j.1469-7793.1999.711ab.x

104. Twyman RE, Macdonald RL (1992) Neurosteroid regulation of GABAA receptor single-channel kinetic properties of mouse spinal cord neurons in culture. J Physiol 456:215-245. https://doi. org/10.1113/jphysiol.1992.sp019334

105. Maconochie DJ, Zempel JM, Steinbach JH (1994) How quickly can GABAA receptors open? Neuron 12:61-71

106. Chang Y, Weiss DS (1999) Channel opening locks agonist onto the GABAC receptor. Nat Neurosci 2:219-225. https://doi.org/ $10.1038 / 6313$

107. Lindquist CEL, Birnir B (2006) Graded response to GABA by native extrasynaptic GABAA receptors. J Neurochem 97:13491356. https://doi.org/10.1111/j.1471-4159.2006.03811.x 
108. Korpi ER, Mihalek RM, Sinkkonen ST et al (2002) Altered receptor subtypes in the forebrain of GABAA receptor $\delta$ subunit-deficient mice: recruitment of $\gamma 2$ subunits. Neuroscience 109:733-743. https://doi.org/10.1016/S0306-4522(01)00527-9

109. Feng H, Jounaidi Y, Haburcak M et al (2014) Etomidate produces similar allosteric modulation in $\alpha 1 \beta 3 \delta$ and $\alpha 1 \beta 3 \gamma 2 \mathrm{~L} \mathrm{GABA}_{\mathrm{A}}$ receptors. Br J Pharmacol 171:789-798. https://doi.org/10.1111/ bph.12507

110. Gingrich KJ, Roberts WA, Kass RS (1995) Dependence of the GABAA receptor gating kinetics on the alpha-subunit isoform: implications for structure-function relations and synaptic transmission. J Physiol 489:529-543. https://doi.org/10.1113/jphys iol.1995.sp021070

111. Picton AJ, Fisher JL (2007) Effect of the $\alpha$ subunit subtype on the macroscopic kinetic properties of recombinant GABAA receptors. Brain Res 1165:40-49. https://doi.org/10.1016/j.brainres. 2007.06.050

112. Lagrange AH, Botzolakis EJ, Macdonald RL (2007) Enhanced macroscopic desensitization shapes the response of $\alpha 4$ subtypecontaining $\mathrm{GABA}_{\mathrm{A}}$ receptors to synaptic and extrasynaptic GABA: enhanced fast desensitization in $\alpha 4$ subunit-containing $\mathrm{GABA}_{\mathrm{A}}$ receptors. J Physiol 578:655-676. https://doi.org/10. 1113/jphysiol.2006.122135

113. Brown N, Kerby J, Bonnert TP et al (2002) Pharmacological characterization of a novel cell line expressing human $\alpha 4 \beta 3 \delta$ GABAA receptors. Br J Pharmacol 136:965-974. https://doi.org/ 10.1038/sj.bjp.0704795

114. Haas KF, Macdonald RL (1999) GABAA receptor subunit $\gamma 2$ and $\delta$ subtypes confer unique kinetic properties on recombinant GABAA receptor currents in mouse fibroblasts. J Physiol 514:27-45. https://doi.org/10.1111/j.1469-7793.1999.027af.x

115. Olander ER, Janzen D, Villmann C, Jensen A (2020) Comparison of biophysical properties of $\mathrm{a} 1 \mathrm{~b} 2$ and $\mathrm{a} 3 \mathrm{~b} 2$ GABAA receptors in whole-cell patch-clamp electrophysiological recordings. PLoS ONE 15:e0234080. https://doi.org/10.1371/journal.pone.02340 80

116. Enz R, Cutting GR (1999) GABAC receptor $\rho$ subunits are heterogeneously expressed in the human CNS and form homo- and heterooligomers with distinct physical properties: analysis of individually and coexpressed $\rho$ subunits. Eur J Neurosci 11:4150. https://doi.org/10.1046/j.1460-9568.1999.00423.x

117. Belujon P, Baufreton J, Grandoso L et al (2009) Inhibitory transmission in locus coeruleus neurons expressing GABAA receptor epsilon subunit has a number of unique properties. J Neurophysiol 102:2312-2325

118. Mazzuferi M, Palma E, Martinello K et al (2010) Enhancement of GABAA-current run-down in the hippocampus occurs at the first spontaneous seizure in a model of temporal lobe epilepsy. Proc Natl Acad Sci 107:3180-3185. https://doi.org/10.1073/ pnas.0914710107

119. Tureček R, Trussell LO (2000) Control of synaptic depression by glutamate transporters. J Neurosci 20:2054-2063. https://doi. org/10.1523/JNEUROSCI.20-05-02054.2000

120. Gielen M, Barilone N, Corringer P-J (2020) The desensitization pathway of GABAA receptors, one subunit at a time. Nat Commun 11:5369. https://doi.org/10.1038/s41467-020-19218-6

121. Ortinski PI, Lu C, Takagaki K et al (2004) Expression of distinct $\alpha$ subunits of $\mathrm{GABA}_{\mathrm{A}}$ receptor regulates inhibitory synaptic strength. J Neurophysiol 92:1718-1727. https://doi.org/10.1152/ jn.00243.2004

122. Fisher JL (2004) A mutation in the GABAA receptor $\alpha 1$ subunit linked to human epilepsy affects channel gating properties. Neuropharmacology 46:629-637. https://doi.org/10.1016/j.neuro pharm.2003.11.015

123. Bianchi MT, Haas KF, Macdonald RL (2002) $\alpha 1$ and $\alpha 6$ subunits specify distinct desensitization, deactivation and neurosteroid modulation of GABAA receptors containing the $\delta$ subunit. Neuropharmacology 43:492-502. https://doi.org/10.1016/S00283908(02)00163-6

124. Burgard C, Tietz I, Neelands R, Macdonald L (1996) Proper-

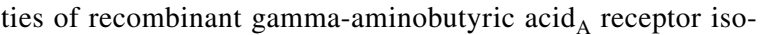
forms containing the alpha5 subunit subtype. Mol Pharmacol 50:119-127

125. Saxenal NC, Macdonald L (1994) Assembly of GABA, receptor subunits: role of the delta subunit. J Neurosci 14:7077-7086

126. Whiting PJ, McAllister G, Vassilatis D et al (1997) Neuronally restricted RNA splicing regulates the expression of a novel GABAA receptor subunit conferring atypical functional properties. J Neurosci 17:5027-5037. https://doi.org/10.1523/JNEUR OSCI.17-13-05027.1997

127. Qian H, Dowling JE (1993) Novel GABA responses from roddriven retinal horizontal cells. Nature 361:162-164. https://doi. org/10.1038/361162a0

128. Feigenspan A, Bormann J (1998) GABA-gated CI-channels in the rat retina. Prog Retin Eye Res 17:99-126

129. Che Has A, Absalom N, van Nieuwenhuijzen P et al (2016) Zolpidem is a potent stoichiometry-selective modulator of a1b3 GABAA receptors: evidence of a novel benzodiazepine site in the a1-a1 interface. Sci Rep 6:28674. https://doi.org/ 10.1038/srep28674

130. Fisher JL, Macdonald RL (1997) Single channel properties of recombinant $\mathrm{GABA}_{\mathrm{A}}$ receptors containing $\gamma 2$ or $\delta$ subtypes expressed with $\alpha 1$ and $\beta 3$ subtypes in mouse L929 cells. J Physiol 505:283-297. https://doi.org/10.1111/j.1469-7793. 1997.283bb.x

131. Overstreet LS, Jones MV, Westbrook GL (2000) Slow desensitization regulates the availability of synaptic $\mathrm{GABA}_{\mathrm{A}}$ receptors. J Neurosci 20:7914-7921. https://doi.org/10.1523/JNEUR OSCI.20-21-07914.2000

132. Germann AL, Pierce SR, Senneff TC et al (2019) Steadystate activation and modulation of the synaptic-type $\alpha 1 \beta 2 \gamma 2 \mathrm{~L}$ GABAA receptor by combinations of physiological and clinical ligands. Physiol Rep 7:e14230. https://doi.org/10.14814/ phy2.14230

133. Burgard EC, Haas KF, Macdonald RL (1999) Channel properties determine the transient activation kinetics of recombinant GABAA receptors. Mol Brain Res 73:28-36. https://doi.org/10. 1016/S0169-328X(99)00230-2

134. Overstreet LS, Westbrook GL (2002) Measuring and modeling the spatiotemporal profile of GABA at the synapse. Transmembrane transporters, 1st edn. Wiley, New York, pp 259-275

135. Bianchi MT, Macdonald RL (2001) Agonist Trapping by GABA receptor channels. J Neurosci 21:9083-9091. https://doi.org/10. 1523/JNEUROSCI.21-23-09083.2001

136. Baker PM, Pennefather PS, Orser BA, Skinner FK (2002) Disruption of coherent oscillations in inhibitory networks with anesthetics: role of $\mathrm{GABA}_{\mathrm{A}}$ receptor desensitization. J Neurophysiol 88:2821-2833. https://doi.org/10.1152/jn.00052.2002

137. Kaneda M, Farrant M, Cull-Candy SG (1995) Whole-cell and single-channel currents activated by GABA and glycine in granule cells of the rat cerebellum. J Physiol 485:419-435. https:// doi.org/10.1113/jphysiol.1995.sp020739

138. Boileau AJ, Li T, Benkwitz C et al (2003) Effects of $\gamma 2 \mathrm{~S}$ subunit incorporation on GABAA receptor macroscopic kinetics. Neuropharmacology 44:1003-1012. https://doi.org/10.1016/S00283908(03)00114-X

139. Benkwitz C (2004) Influence of GABAA receptor gamma2 splice variants on receptor kinetics and isoflurane modulation. Anesthesiology 101:924-936

140. Lagrange A, Macdonald R (2005) Enhanced desensitization in alpha4 containing GABAA receptors. Epilepsia 46:113 
141. Macdonald RL, Rogers CJ, Twyman RE (1989) Kinetic properties of the GABAA receptor main conductance state of mouse spinal cord neurones in culture. J Physiol 410:479-499. https:// doi.org/10.1113/jphysiol.1989.sp017545

142. Twyman RE, Rogers CJ, Macdonald RL (1990) Intraburst kinetic properties of the GABAA receptor main conductance state of mouse spinal cord neurones in culture. J Physiol 423:193-220. https://doi.org/10.1113/jphysiol.1990.sp018018

143. Colquhoun D, Hawkes AG (1995) The principles of the stochastic interpretation of ion-channel mechanisms. In: Sakmann B, Neher E (eds) Single-channel recording. Springer US, Boston, pp 397-482

144. Chang Y, Ghansah E, Chen Y et al (2002) Desensitization mechanism of GABA receptors revealed by single oocyte binding and receptor function. J Neurosci 22:7982-7990. https://doi.org/10. 1523/JNEUROSCI.22-18-07982.2002

145. Angelotti TP, Macdonald RL (1993) Assembly of GABA, receptor subunits: alpha1beta1 and alpha1beta1gamma2S subunits produce unique ion channels with dissimilar singlechannel properties. J Neurosci 13:1429-1440

146. Angelotti TP, Uhler D, McDonald BJ (1993) Assembly of GABA, receptor subunits: analysis of transient single-cell expression utilizing a fluorescent substrate/marker gene technique. J Neurosci 13:1418-1428

147. Feigenspan A, Bormann J (1994) Differential pharmacology of GABAA and GABAC receptors on rat retinal bipolar cells. Eur J Pharmacol Mol Pharmacol 288:97-104. https://doi.org/ 10.1016/0922-4106(94)90014-0

148. Feigenspan A, Wässle H, Bormann J (1993) Pharmacology of GABA receptor $\mathrm{CI}$-channels in rat retinal bipolar cells. Nature 361:159-162. https://doi.org/10.1038/361159a0

149. Sigworth FJ (1980) The variance of sodium current fluctuations at the node of Ranvier. J Physiol 307:97-129. https://doi.org/ 10.1113/jphysiol.1980.sp013426

150. Olsen RW (1982) Drug interactions at the GABA receptorionophore complex. Annu Rev Pharmacol Toxicol 22:245-277. https://doi.org/10.1146/annurev.pa.22.040182.001333

151. Böhme I, Rabe H, Lüddens H (2004) Four amino acids in the $\alpha$ subunits determine the $\gamma$-aminobutyric acid sensitivities of $\mathrm{GABA}_{\mathrm{A}}$ receptor subtypes. J Biol Chem 279:35193-35200. https://doi.org/10.1074/jbc.M405653200

152. Verdoorn A (1990) Functional properties of recombinant rat GABAA receptors depend upon subunit composition. Neuron 4:919-928

153. Sigel E, Baur R (2002) Electrophysiological evidence for the coexistence of $\alpha 1$ and $\alpha 6$ subunits in a single functional GABAA receptor. J Neurochem 74:2590-2596. https://doi.org/ 10.1046/j.1471-4159.2000.0742590.x

154. Sigel E, Baur R, Trube $G$ et al (1990) The effect of subunit composition of rat brain GABAA receptors on channel function. Neuron 5:703-711

155. Hansen SL, Ebert B, Fjalland B, Kristiansen U (2001) Effects of GABAA receptor partial agonists in primary cultures of cerebellar granule neurons and cerebral cortical neurons reflect different receptor subunit compositions. Br J Pharmacol 133:539-549. https://doi.org/10.1038/sj.bjp.0704121

156. Hevers W, Korpi ER, Lüddens H (2000) Assembly of functional $\alpha 6 \beta 3 \gamma 2 \delta$ GABAA receptors in vitro. NeuroReport 11:4103-4106

157. Fisher JL, Macdonald RL (1997) Functional properties of recombinant GABAA receptors composed of single or multiple $\beta$ subunit subtypes. Neuropharmacology 36:1601-1610. https://doi.org/ 10.1016/S0028-3908(97)00133-0

158. Dostalova Z, Zhou X, Liu A et al (2014) Human $\alpha 1 \beta 3 \gamma 2 \mathrm{~L}$ gamma-aminobutyric acid type A receptors: high-level production and purification in a functional state: purification of functional $\alpha 1 \beta 3 \gamma 2$ GABAA receptors. Protein Sci 23:157-166. https://doi.org/10.1002/pro.2401

159. Legendre P, Muller E, Badiu CI et al (2002) Desensitization of homomeric $\alpha 1$ glycine receptor increases with receptor density. Mol Pharmacol 62:817-827. https://doi.org/10.1124/mol.62.4. 817

160. Davies PA, Kirkness EF, Hales TG (1997) Modulation by general anaesthetics of rat GABAA receptors comprised of $\alpha 1 \beta 3$ and $\beta 3$ subunits expressed in human embryonic kidney 293 cells. Br J Pharmacol 120:899-909. https://doi.org/10.1038/sj.bjp.0700987

161. Neelands TR, Fisher JL, Bianchi M, Macdonald RL (1999) Spontaneous and gamma-aminobutyric acid (GABA)-activated GABAA receptor channels formed by epsilon subunit-containing isoforms. Mol Pharmacol 1:168-178

162. López-Chávez A, Miledi R, Martínez-Torres A (2005) Cloning and functional expression of the bovine GABAC $\rho 2$ subunit. Neurosci Res 53:421-427. https://doi.org/10.1016/j.neures.2005. 08.014

163. Ebert B, Wafford KA, Whiting PJ et al (1994) Molecular pharmacology of gamma-aminobutyric acid type A receptor agonists and partial agonists in oocytes injected with different alpha, beta, and gamma receptor subunit combinations. Mol Pharmacol 46:957-963

164. Wafford KA, Bain CJ, Whiting PJ, Kemp JA (1993) Functional comparison of the role of gamma subunits in recombinant human gamma-aminobutyric acidA/benzodiazepine receptors. Mol Pharmacol 44:437-442

165. Horne AL, Harkness PC, Hadingham KL et al (1993) The influence of the $\gamma 2 \mathrm{~L}$ subunit on the modulation of responses to GABAA receptor activation. Br J Pharmacol 108:711-716. https://doi.org/10.1111/j.1476-5381.1993.tb12866.x

166. Malherbe P, Draguhn A, Multhaup G (1990) GABAA-receptor expressed from rat brain a- and fl-subunit cDNAs displays potentiation by benzodiazepine receptor ligands. Mol Brain Res 8:199-208

167. Ducić I, Caruncho HJ, Zhu WJ et al (1995) gamma-Aminobutyric acid gating of $\mathrm{Cl}$ - channels in recombinant GABAA receptors. J Pharmacol Exp Ther 272:438-445

168. Hadingham KL, Harkness PC, McKernan RM et al (1992) Stable expression of mammalian type A gamma-aminobutyric acid receptors in mouse cells: demonstration of functional assembly of benzodiazepine-responsive sites. Proc Natl Acad Sci 89:63786382. https://doi.org/10.1073/pnas.89.14.6378

169. Horne AL, Hadingham KL, Macaulay AJ et al (1992) The pharmacology of recombinant GABAA receptors containing bovine $\alpha 1, \beta 1, \gamma 2 \mathrm{~L}$ sub-units stably transfected into mouse fibroblast L-cells. Br J Pharmacol 107:732-737. https://doi.org/10.1111/j. 1476-5381.1992.tb14515.x

170. Krishek BJ, Amato A, Connolly CN et al (1996) Proton sensitivity of the $\operatorname{GABA}(\mathrm{A})$ receptor is associated with the receptor subunit composition. J Physiol 492:431-443. https://doi.org/10. 1113/jphysiol.1996.sp021319

171. Saxena NC, Macdonald RL (1996) Properties of putative cerebellar gamma-aminobutyric acid A receptor isoforms. Mol Pharmacol 49:567-579

172. Kleingoor C, Wieland H, Korpi ER et al (1993) Current potentiation by diazepam but not GABA sensitivity is determined by a single histidine residue. NeuroReport 4:187-190

173. Amin J, Weiss DS (1993) GABAA receptor needs two homologous domains of the \& beta;-subunit for activation by GABA but not by pentobarbital. Nature 366:565-569. https://doi.org/ $10.1038 / 366565 \mathrm{a} 0$

174. Chang Y, Wang R, Barot S, Weiss DS (1996) Stoichiometry of a recombinant GABAA receptor. J Neurosci 16:5415-5424. https://doi.org/10.1523/JNEUROSCI.16-17-05415.1996 
175. Baumann SW, Baur R, Sigel E (2003) Individual properties of the two functional agonist sites in $\mathrm{GABA}_{\mathrm{A}}$ receptors. J Neurosci 23:11158-11166. https://doi.org/10.1523/JNEUROSCI.23-3511158.2003

176. Connolly CN, Krishek BJ, McDonald BJ et al (1996) Assembly and cell surface expression of heteromeric and homomeric-aminobutyric acid type A receptors. J Biol Chem 271:89-96. https:// doi.org/10.1074/jbc.271.1.89

177. Falk-Petersen C, Tsonkov T, Nielsen MS et al (2020) Discovery of a new class of orthosteric antagonists with nanomolar potency at extrasynaptic GABAA receptors. Sci Rep 10:10078. https:// doi.org/10.1038/s41598-020-66821-0

178. Herb A, Wisden W, Luddens H et al (1992) The third gamma subunit of the gamma-aminobutyric acid type A receptor family. Proc Natl Acad Sci USA 89:1433-1437

179. L'Estrade E, Hansen H, Falk-Petersen C et al (2019) Synthesis and pharmacological evaluation of [11C]4-methoxy- $N$ [2-(thiophen-2-yl)imidazo[1,2-a]pyridin-3-yl]benzamide as a brain penetrant PET ligand selective for the d-subunit-containing gamma-aminobutyric acid type A receptors. ACS Omega 4:8846-8851. https://doi.org/10.1021/acsomega.9b00434

180. Mortensen M, Smart TG (2006) Extrasynaptic $\alpha \beta$ subunit GABA receptors on rat hippocampal pyramidal neurons: extrasynaptic $\mathrm{GABA}_{\mathrm{A}}$ receptor isoforms. J Physiol 577:841-856. https://doi. org/10.1113/jphysiol.2006.117952

181. Feng H-J, Macdonald RL (2004) Proton modulation of $\alpha 1 \beta 3 \delta$ GABAA receptor channel gating and desensitization. J Neurophysiol 92:1577-1585. https://doi.org/10.1152/jn.00285.2004

182. Nagaya N, Macdonald RL (2001) Two $\gamma 2 \mathrm{~L}$ subunit domains confer low $\mathrm{Zn}^{2+}$ sensitivity to ternary GABAA receptors. J Physiol 532:17-30. https://doi.org/10.1111/j.1469-7793.2001.0017g.x

183. Wafford KA, Whiting PJ, Kemp JA (1993) Differences in affinity and efficacy of benzodiazepine receptor ligands at recombinant

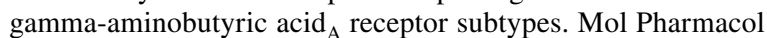
43:240-244

184. Jones MV, Harrison NL, Pritchett DB, Hales TG (1995) Modulation of the GABAA receptor by propofol is independent of the gamma subunit. J Pharmacol Exp Ther 274:962-968

185. Davies PA, Hanna MC, Hales TG, Kirkness EF (1997) Insensitivity to anaesthetic agents conferred by a class of GABAA receptor subunit. Nature 385:820-823. https://doi.org/10.1038/385820a0

186. Ranna M, Sinkkonen S, Möykkynen T et al (2006) Impact of $\varepsilon$ and $\theta$ subunits on pharmacological properties of $\alpha 3 \beta 1$ GABAA receptors expressed in Xenopus oocytes. BMC Pharmacol 6:1. https://doi.org/10.1186/1471-2210-6-1

187. Knoflach F, Drescher U, Scheurer L et al (1993) Full and partial agonism displayed by benzodiazepine receptor ligands at recom-

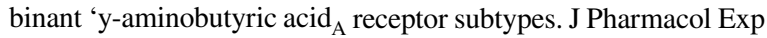
Ther 266:385-391

188. Falk-Petersen C, Sogaard R, Madsen K et al (2017) Develpment of a robus mammalian cell-based assay for studying recombinant a4b1/3D GABAA receptor subtypes. Basic Clin Pharmacol Toxicol 121:119-129. https://doi.org/10.1111/bcpt.12778

189. Knoflach F, Benke D, Wang Y et al (1996) Pharmacological modulation of the diazepam-insensitive recombinant gammaaminobutyric acid $_{\mathrm{A}}$ receptors alpha 4 beta 2 gamma 2 and alpha 6 beta 2 gamma 2. Mol Pharmacol 50:1253-1261

190. Knoflach F, Rhyner Th, Villa M et al (1991) The $\gamma 3$-subunit of the GABAA-receptor confers sensitivity to benzodiazepine receptor ligands. FEBS Lett 293:191-194. https://doi.org/10. 1016/0014-5793(91)81184-A

191. Neelands TR, Macdonald RL (1999) Incorporation of the $\pi$ subu-

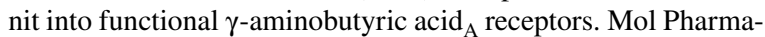
col 56:598-610. https://doi.org/10.1124/mol.56.3.598
192. Qian H, Dowling JE, Ripps H (1998) Molecular and pharmacological properties of GABA-rho subunits from white perch retina. Dev Neurobiol 37:305-320

193. Nguyen Q-A, Nicoll RA (2018) The GABAA receptor $\beta$ subunit is required for inhibitory transmission. Neuron 98:718-725. https://doi.org/10.1016/j.neuron.2018.03.046

194. Craig AM (1994) Selective clustering of glutamate and gammaaminobutyric acid receptors opposite terminals releasing the corresponding neurotransmitters. Proc Natl Acad Sci USA 91:12373-12377

195. Celentano JJ, Wong RK (1994) Multiphasic desensitization of the GABAA receptor in outside-out patches. Biophys J 66:10391050. https://doi.org/10.1016/S0006-3495(94)80885-9

196. Nusser Z, Sieghart W, Somogyi $P$ (1998) Segregation of different $\mathrm{GABA}_{\mathrm{A}}$ receptors to synaptic and extrasynaptic membranes of cerebellar granule cells. J Neurosci 18:1693-1703. https://doi org/10.1523/JNEUROSCI.18-05-01693.1998

197. Essrich C, Lorez M, Benson JA et al (1998) Postsynaptic clustering of major GABAA receptor subtypes requires the $\gamma 2$ subunit and gephyrin. Nat Neurosci 1:563-571. https://doi.org/10.1038/ 2798

198. Farrant M, Nusser Z (2005) Variations on an inhibitory theme: phasic and tonic activation of GABAA receptors. Nat Rev Neurosci 6:215-229. https://doi.org/10.1038/nrn1625

199. Adkins CE, Pillai GV, Kerby J et al (2001) $\alpha 4 \beta 3 \delta$ GABAA receptors characterized by fluorescence resonance energy transfer-derived measurements of membrane potential. J Biol Chem 276:38934-38939. https://doi.org/10.1074/jbc.M1043 18200

200. Wall MJ, Usowicz MM (1997) Development of action potentialdependent and independent spontaneous $\mathrm{GABA}_{\mathrm{A}}$ receptor-mediated currents in granule cells of postnatal rat cerebellum. Eur $\mathrm{J}$ Neurosci 9:533-548. https://doi.org/10.1111/j.1460-9568.1997. tb01630.x

201. Gurba KN (2010) Assembly and heterogeneity of GABAA receptors. Vanderbilt Rev Neurosci 1-2:25-32

202. Scimemi A, Beato M (2009) Determining the neurotransmitter concentration profile at active synapses. Mol Neurobiol 40:289 306. https://doi.org/10.1007/s12035-009-8087-7

203. Galarreta M, Hestrin S (1998) Frequency-dependent synaptic depression and the balance of excitation and inhibition in the neocortex. Nat Neurosci 1:587-594. https://doi.org/10.1038/ 2822

204. Jiang L, Sun S, Nedergaard M, Kang J (2000) Paired-pulse modulation at individual GABAergic synapses in rat hippocampus. $\mathbf{J}$ Physiol 523:425-439. https://doi.org/10.1111/j.1469-7793.2000. t01-1-00425.x

205. Levitan ES, Schofield PR, Burt DR et al (1988) Structural and functional basis for GABAA receptor heterogeneity. Nature 335:76-79. https://doi.org/10.1038/335076a0

206. Nusser Z, Sieghartt W, Benket D et al (1996) Differential synaptic localization of two major gamma-aminobutyric acid type A receptor alpha subunits on hippocampal pyramidal cells. Proc Natl Acad Sci USA 93:11939-11944

207. Nusser Z, Sieghart W, Stephenson FA, Somogyil P (1996) The alpha6 subunit of the GABA, receptor is concentrated in both inhibitory and excitatory synapses on cerebellar granule cells. $\mathbf{J}$ Neurosci 16:103-114

208. Koulen P, Tter JHB, Ger SK et al (1997) Immunocytochemical localization of the GABAC receptor $r$ subunits in the cat, goldfish, and chicken retina. J Comp Neurol 380:520-532

209. Huntsman MM, Huguenard JR (2006) Fast IPSCs in rat thalamic reticular nucleus require the GABA $\mathrm{A}_{\mathrm{A}}$ receptor $\beta_{1}$ subunit: molecular basis of fast IPSCs in RTN cells. J Physiol 572:459-475. https://doi.org/10.1113/jphysiol.2006.106617 
210. Enz R (1996) Immunocytochemical localization of the GABAC receptor subunits in the mammalian retina. J Neurosci 16:4479-4490

211. Pan Z, Lipton S (1995) Multiple GABA receptor subtypes mediate inhibition of calcium influx at rat retinal bipolar cell terminals. J Neurosci 15:2668-2679. https://doi.org/10.1523/JNEUR OSCI.15-04-02668.1995

212. Kapousta-Bruneau NV (2000) Opposite effects of GABAA and GABAC receptor antagonists on the b-wave of ERG recorded from the isolated rat retina. Vis Res 40:1653-1665. https://doi. org/10.1016/S0042-6989(00)00028-6

213. Shields CR, Tran MN, Wong ROL, Lukasiewicz PD (2000) Distinct ionotropic GABA receptors mediate presynaptic and postsynaptic inhibition in retinal bipolar cells. J Neurosci 20:26732682. https://doi.org/10.1523/JNEUROSCI.20-07-02673.2000

214. Euler T, Wässle H (1998) Different contributions of GABA ${ }_{A}$ and GABA $_{C}$ receptors to rod and cone bipolar cells in a rat retinal slice preparation. J Neurophysiol 79:1384-1395. https://doi.org/ 10.1152/jn.1998.79.3.1384

215. Zhang J, Jung C-S, Slaughter MM (1997) Serial inhibitory synapses in retina. Vis Neurosci 14:553-563. https://doi.org/10. 1017/S0952523800012219

216. Carlson BX, Elster L, Schousboe A (1998) Pharmacological and functional implications of developmentally-regulated changes in GABAA receptor subunit expression in the cerebellum. Eur $\mathbf{J}$ Pharmacol 352:1-14. https://doi.org/10.1016/S0014-2999(98) 00355-0

217. Tia S, Wang JF, Kotchabhakdi N, Vicini S (1996) Developmental changes of inhibitory synaptic currents in cerebellar granule neurons: role of GABAA receptor $\alpha 6$ subunit. J Neurosci $16: 3630-3640$

218. Quick M, Corey JL, Davidson N, Lester HA (1997) Second messengers, trafficking-related proteins, and amino acid residues that contribute to the functional regulation of the rat brain GABA transporter GAT1. J Neurosci 17:2967-2979

219. Corey JL, DavidsonS N, Lester HA, Brechan N (1994) Protein kinase $\mathrm{C}$ modulates the activity of a cloned y-aminobutyric acid transporter expressed in Xenopus oocytes via regulated subcellular redistribution of the transporter. J Biol Chem 269:14759-14767

220. Gulledge AT, Stuart GJ (2003) Excitatory actions of GABA in the cortex. Neuron 37:299-309. https://doi.org/10.1016/S08966273(02)01146-7

221. Williams SR, Stuart GJ (2003) Voltage- and site-dependent control of the somatic impact of dendritic IPSPs. J Neurosci 23:7358-7367. https://doi.org/10.1523/JNEUROSCI.23-1907358.2003

222. Hamann M, Rossi DJ, Attwell D (2002) Tonic and spillover inhibition of granule cells control information flow through cerebellar cortex. Neuron 33:625-633. https://doi.org/10.1016/S08966273(02)00593-7

223. Banks MI, Pearce RA (2000) Kinetic differences between synaptic and extrasynaptic $\mathrm{GABA}_{\mathrm{A}}$ receptors in CA1 pyramidal cells. J Neurosci 20:937-948. https://doi.org/10.1523/JNEUROSCI. 20-03-00937.2000

224. Li P, Akk G (2015) Synaptic-type $\alpha 1 \beta 2 \gamma 2$ L GABAA receptors produce large persistent currents in the presence of ambient GABA and anesthetic drugs. Mol Pharmacol 87:776-781. https:// doi.org/10.1124/mol.114.096453

225. Semyanov A, Walker MC, Kullmann DM (2003) GABA uptake regulates cortical excitability via cell type-specific tonic inhibition. Nat Neurosci 6:484-490. https://doi.org/10.1038/nn1043

226. Maex R, Schutter ED (1998) Synchronization of golgi and granule cell firing in a detailed network model of the cerebellar granule cell layer. J Neurophysiol 80:2521-2537. https://doi.org/10. 1152/jn.1998.80.5.2521
227. De Schutter E (2002) Cerebellar cortex: computation by extrasynaptic inhibition? Curr Biol 12:R363-R365. https://doi.org/ 10.1016/S0960-9822(02)00861-8

228. Schweighofer N, Doya K, Lay F (2001) Unsupervised learning of granule cell sparse codes enhances cerebellar adaptive control. Neuroscience 103:35-50. https://doi.org/10.1016/S03064522(00)00548-0

229. Tyrrell T, Willshaw D (1992) Cerebellar cortex: its simulation and the relevance of Marr's theory. Phil Trans R Soc Lond B 336:239-257. https://doi.org/10.1098/rstb.1992.0059

230. Hámori J, Somogyi J (1983) Differentiation of cerebellar mossy fiber synapses in the rat: a quantitative electron microscope study. J Comp Neurol 220:365-377. https://doi.org/10.1002/cne.90220 0402

231. Demarque M, Represa A, Becq H et al (2002) Paracrine intercellular communication by a $\mathrm{Ca}^{2+}$ - and SNARE-independent release of GABA and glutamate prior to synapse formation. Neuron 36:1051-1061. https://doi.org/10.1016/S0896-6273(02)01053-X

232. Mitchell SJ, Silver RA (2003) Shunting inhibition modulates neuronal gain during synaptic excitation. Neuron 38:433-445. https://doi.org/10.1016/S0896-6273(03)00200-9

233. Attwell D, Barbour B, Szatkowski M (1993) Nonvesicular release of neurotransmitter. Neuron 11:401-407. https://doi.org/10.1016/ 0896-6273(93)90145-H

234. Birnir B, Everitt AB, Lim MSF, Gage PW (2000) Spontaneously opening $\mathrm{GABA}_{\mathrm{A}}$ channels in CA1 pyramidal neurones of rat hippocampus. J Membr Biol 174:21-29. https://doi.org/10. $1007 / \mathrm{s} 002320001028$

235. Rossi DJ, Hamann M (1998) Spillover-mediated transmission at inhibitory synapses promoted by high affinity $\alpha 6$ subunit GABAA receptors and glomerular geometry. Neuron 20:783-795

236. Barbour B, Häusser M (1997) Intersynaptic diffusion of neurotransmitter. Trends Neurosci 20:377-384

237. Rudomín P, Engberg I, Jiménez I (1981) Mechanisms involved in presynaptic depolarization of group I and rubrospinal fibers in cat spinal cord. J Neurophysiol 46:532-548. https://doi.org/ 10.1152/jn.1981.46.3.532

238. Curtis DR, Lodge D (1982) The depolarization of feline ventral horn group Ia spinal afferent terminations by GABA. Exp Brain Res 46:215-233. https://doi.org/10.1007/BF00237180

239. Stell BM, Rostaing P, Triller A, Marty A (2007) Activation of presynaptic GABAA receptors induces glutamate release from parallel fiber synapses. J Neurosci 27:9022-9031. https://doi.org/ 10.1523/JNEUROSCI.1954-07.2007

240. Stuart GJ, Redman SJ (1992) The role of GABAA and GABAB receptors in presynaptic inhibition of Ia EPSPs in cat spinal motoneurones. J Physiol 447:675-692. https://doi.org/10.1113/ jphysiol.1992.sp019023

241. Pouille F (2001) Enforcement of Temporal fidelity in pyramidal cells by somatic feed-forward inhibition. Science 293:11591163. https://doi.org/10.1126/science. 1060342

242. Walker MC, Ruiz A, Kullmann DM (2001) Monosynaptic GABAergic signaling from dentate to CA3 with a pharmacological and physiological profile typical of mossy fiber synapses. Neuron 29:703-715. https://doi.org/10.1016/S0896-6273(01) 00245-8

243. Bergersen L, Ruiz A, Bjaalie JG et al (2003) GABA and GABAA receptors at hippocampal mossy fibre synapses. Eur J Neurosci 18:931-941. https://doi.org/10.1046/j.1460-9568.2003.02828.x

244. Pouzat C, Marty A (1999) Somatic recording of GABAergic autoreceptor current in cerebellar stellate and basket cells. J Neurosci 19:1675-1690. https://doi.org/10.1523/JNEUROSCI. 19-05-01675.1999

245. Rudomin P, Schmidt RF (1999) Presynaptic inhibition in the vertebrate spinal cord revisited. Exp Brain Res 129:1-37. https:// doi.org/10.1007/s002210050933 
246. Sagdullaev BT, McCall MA, Lukasiewicz PD (2006) Presynaptic inhibition modulates spillover, creating distinct dynamic response ranges of sensory output. Neuron 50:923-935. https:// doi.org/10.1016/j.neuron.2006.05.015

247. Filippova N, Dudley R, Weiss DS (1999) Evidence for phosphorylation-dependent internalization of recombinant human $\rho 1$ GABA $_{C}$ receptors. J Physiol 518:385-399. https://doi.org/ 10.1111/j.1469-7793.1999.0385p.x

248. Leidenheimer NJ, Whiting PJ, Harris RA (1993) Activation of calcium-phospholipid-dependent protein kinase enhances benzodiazepine and barbiturate potentiation of the $\mathrm{GABA}_{\mathrm{A}}$ receptor. $\mathrm{J}$ Neurochem 60:1972-1975. https://doi.org/10.1111/j.1471-4159. 1993.tb13432.x

249. Gyenes M, Wang Q, Gibbs T, Farb H (1994) Phosphorylation factors control neurotransmitter and actions at the gamma-aminobutyric acid type A receptor. Mol Pharmacol 46:542-549

250. Moss S, Smart T, Blackstone C, Huganir R (1992) Functional modulation of GABAA receptors by cAMP-dependent protein phosphorylation. Science 257:661-665. https://doi.org/10.1126/ science. 1323140

251. Poisbeau P, Cheney MC, Browning MD, Mody I (1999) Modulation of synaptic GABAA receptor function by PKA and PKC in adult hippocampal neurons. J Neurosci 19:674-683. https://doi. org/10.1523/JNEUROSCI.19-02-00674.1999

252. Kapur J, Macdonald RL (1996) Cyclic AMP-dependent protein kinase enhances hippocampal dentate granule cell GABAA receptor currents. J Neurophysiol 76:2626-2634. https://doi.org/ 10.1152/jn.1996.76.4.2626

253. Cheun JE, Yeh HH (1992) Modulation of GABAA receptor-activated current by norepinephrine in cerebellar purkinje cells. Neuroscience 51:951-960. https://doi.org/10.1016/0306-4522(92) 90532-7

254. Collinson N, Cothliff R, Rosahl TW et al (2000) Role of the alpha 5 subunit of the GABA-A receptor in learning and memory. European journal of neuroscience. Blackwell Science Ltd, Oxford, pp 171-171

255. Hinkle DJ, Macdonald RL (2003) Beta subunit phosphorylation selectively increases fast desensitization and prolongs deactivation of alpha1beta1gamma2L and alpha1beta3gamma2L GABAA receptor currents. J Neurosci 23:11698-11710

256. Liu F, Wan Q, Pristupa ZB et al (2000) Direct protein-protein coupling enables cross-talk between dopamine D5 and $\gamma$-aminobutyric acid A receptors. Nature 403:274-280. https:// doi.org/10.1038/35002014

257. Sokolova E, Nistri A, Giniatullin R (2001) Negative cross talk between anionic $\mathrm{GABA}_{\mathrm{A}}$ and cationic $\mathrm{P} 2 \mathrm{X}$ ionotropic receptors of rat dorsal root ganglion neurons. J Neurosci 21:4958-4968. https://doi.org/10.1523/JNEUROSCI.21-14-04958.2001

258. Lewis CA, Faber DS (1993) GABA responses and their partial occlusion by glycine in cultured rat medullary neurons. Neuroscience 52:83-96. https://doi.org/10.1016/0306-4522(93)90184-H

259. Li Y, Wu L-J, Legendre P, Xu T-L (2003) Asymmetric crossinhibition between GABAA and glycine receptors in rat spinal dorsal horn neurons. J Biol Chem 278:38637-38645. https://doi. org/10.1074/jbc.M303735200

260. Muir J, Arancibia-Carcamo IL, MacAskill AF et al (2010) NMDA receptors regulate GABAA receptor lateral mobility and clustering at inhibitory synapses through serine 327 on the 2 subunit. Proc Natl Acad Sci 107:16679-16684. https://doi.org/ 10.1073/pnas.1000589107

261. Petrini EM, Zacchi P, Barberis A et al (2003) Declusterization of GABAA receptors affects the kinetic properties of GABAergic currents in cultured hippocampal neurons. J Biol Chem 278:16271-16279. https://doi.org/10.1074/jbc.M213081200

262. Petrini EM, Marchionni I, Zacchi P et al (2004) Clustering of extrasynaptic GABAA receptors modulates tonic inhibition in cultured hippocampal neurons. J Biol Chem 279:45833-45843. https://doi.org/10.1074/jbc.M407229200

263. Chen L, Wang H, Vicini S, Olsen RW (2000) The gammaaminobutyric acid type A (GABAA) receptor-associated protein (GABARAP) promotes GABAA receptor clustering and modulates the channel kinetics. Proc Natl Acad Sci 97:11557-11562. https://doi.org/10.1073/pnas.190133497

264. Weiss DS (1988) Membrane potential modulates the activation of GABA-gated channels. J Neurophysiol 59:514-527. https:// doi.org/10.1152/jn.1988.59.2.514

265. Akaike N, Oyama Y, Yakushiji T (1989) Influences of external $\mathrm{Ca}^{2+}$ on the GABA-induced chloride current and the efficacy of diazepam in internally perfused frog sensory neurons. Brain Res 504:293-296. https://doi.org/10.1016/0006-8993(89)91371-1

266. Kaneda M, Mochizuki M, Aoki K, Kaneko A (1997) Modulation of GABAC response by $\mathrm{Ca}^{2+}$ and other divalent cations in horizontal cells of the catfish retina. J Genet Physiol 110:741-747

267. Akopian A, Gabriel R, Witkovsky P (1998) Calcium released from intracellular stores inhibits $\mathrm{GABA}_{\mathrm{A}}$-mediated currents in ganglion cells of the turtle retina. J Neurophysiol 80:1105-1115. https://doi.org/10.1152/jn.1998.80.3.1105

268. De Koninck Y, Mody I (1996) The effects of raising intracellular

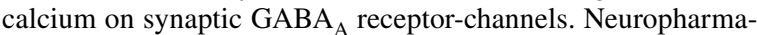
cology 35:1365-1374. https://doi.org/10.1016/S0028-3908(96) 00063-9

269. Taleb O, Trouslard J, Demeneix BA et al (1987) Spontaneous and GABA-evoked chloride channels on pituitary intermediate lobe cells and their internal Ca requirements. Pflugers Arch Eur J Physiol 409:620-631. https://doi.org/10.1007/BF00584663

270. Frederickson CJ, Danscher G (1990) Chapter 6 zinc-containing neurons in hippocampus and related CNS structures. Progress in brain research. Elsevier, pp 71-84

271. Smart TG (1992) A novel modulatory binding site for zinc on the GABAA receptor complex in cultured rat neurones. J Physiol 447:587-625. https://doi.org/10.1113/jphysiol.1992.sp019020

272. Smart TG, Moss SJ, Xie X, Huganir RL (1991) GABAA receptors are differentially sensitive to zinc: dependence on subunit composition. Br J Pharmacol 103:1837-1839. https://doi.org/10. 1111/j.1476-5381.1991.tb12337.x

273. Krishek BJ, Moss SJ, Smart TG (1998) Interaction of $\mathrm{H}^{+}$and $\mathrm{Zn}^{2+}$ on recombinant and native rat neuronal GABAA receptors. J Physiol 507:639-652. https://doi.org/10.1111/j.1469-7793. 1998.639bs.x

274. Hosie AM, Dunne EL, Harvey RJ, Smart TG (2003) Zincmediated inhibition of GABAA receptors: discrete binding sites underlie subtype specificity. Nat Neurosci 6:362-369. https://doi. org/10.1038/nn1030

275. Pasternack M, Bountra C, Voipio J, Kaila K (1992) Influence of extracellular and intracellular $\mathrm{pH}$ on GABA-gated chloride conductance in crayfish muscle fibres. Neuroscience 47:921-929. https://doi.org/10.1016/0306-4522(92)90040-9

276. Kisiel M, Jatczak-Śliwa M, Mozrzymas JW (2019) Protons modulate gating of recombinant $\alpha 1 \beta 2 \gamma 2$ GABAA receptor by affecting desensitization and opening transitions. Neuropharmacology 146:300-315. https://doi.org/10.1016/j.neuropharm.2018.10.016

277. Rivera C, Wegelius K, Reeben M et al (2000) Different sensitivities of human and rat $\rho 1$ GABA receptors to extracellular pH. Neuropharmacology 39:977-989. https://doi.org/10.1016/ S0028-3908(99)00208-7

278. Wegelius K, Reeben M, Rivera C et al (1996) The rho 1 GABA receptor cloned from rat retina is down-modulated by protons. NeuroReport 7:2005-2009. https://doi.org/10.1097/00001756199608120-00030

279. Onodera K, Takeuchi A (1979) An analysis of the inhibitory post-synaptic current in the voltage-clamped crayfish muscle. 
J Physiol 286:265-282. https://doi.org/10.1113/jphysiol.1979. sp012618

280. Limon A, Delbruck E, Yassine A et al (2019) Electrophysiological evaluation of extracellular spermine and alkaline $\mathrm{pH}$ on synaptic human GABAA receptors. Transl Psychiatry 9:218. https:// doi.org/10.1038/s41398-019-0551-1

281. Krishtal OA, Osipchuk YuV, Shelest TN, Smirnoff SV (1987) Rapid extracellular $\mathrm{pH}$ transients related to synaptic transmission in rat hippocampal slices. Brain Res 436:352-356. https://doi. org/10.1016/0006-8993(87)91678-7

282. Traynelis S, Hartley M, Heinemann S (1995) Control of proton sensitivity of the NMDA receptor by RNA splicing and polyamines. Science 268:873-876. https://doi.org/10.1126/science. 7754371

283. Sinning A, Hübner CA (2013) Minireview: pH and synaptic transmission. FEBS Lett 587:1923-1928. https://doi.org/10. 1016/j.febslet.2013.04.045

284. Kaila K, Saarikoski J, Voipio J (1990) Mechanism of action of GABA on intracellular $\mathrm{pH}$ and on surface $\mathrm{pH}$ in crayfish muscle fibres. J Physiol 427:241-260. https://doi.org/10.1113/jphysiol. 1990.sp018170

285. El-Beheiry H, Puil E (1990) Effects of hypomagnesia on transmitter actions in neocortical slices. Br J Pharmacol 101:10061010. https://doi.org/10.1111/j.1476-5381.1990.tb14197.x

286. Duchen MR, Valdeolmillos M, O'Neill SC, Eisner DA (1990) Effects of metabolic blockade on the regulation of intracellular calcium in dissociated mouse sensory neurones. J Physiol 424:411-426. https://doi.org/10.1113/jphysiol.1990.sp018074

287. Inoue $M$, Oomura Y, Yakushiji T, Akaike N (1986) Intracellular calcium ions decrease the affinity of the GABA receptor. Nature 324:156-158. https://doi.org/10.1038/324156a0

Publisher's Note Springer Nature remains neutral with regard to jurisdictional claims in published maps and institutional affiliations. 